УДК 94 (477.73) «1942-1945» (093.3)

DOI: https://doi.org/10.33782/eminak2019.3(27).319

\title{
КОЛЕКЦІЯ ПОВОЄННИХ СПОГАДІВ ОСТАРБАЙТЕРІВ 3 МИКОЛАЇВЩИНИ: ВІД ІНФОРМАТИВНОГО ПОТЕНЦІАЛУ ДО МІКРОІСТОРІЇ
}

\author{
Анатолій Погорєлов \\ Миколаївський національний університет ім. В.О. Сухомлинського (Миколаїв, Україна) \\ e-mail: pogorelov81@meta.ua \\ ORCID: https://orcid.org/0000-0002-6566-4241
}

Аналізується інформативний потенціал повоєнних спогадів колишніх примусових працівників Миколаївщини. Розкрито основні мікроісторичні сюжети й особливості даного корпусу історичних джерел. Зазначено, що досліджувана колекція документів Державного архіву Миколаївської області є цінним джерелом з вивчення окремих аспектів довоєнної історії, періоду нацистської окупації, а також повсякденного життя наших земляків в умовах примусової чи рабської праці, повоєнного руху репатріантів. Підкреслено, що на повноті відображення власного досвіду примусової праці на території Третього рейху у даній колекції позначились ті обставини, що вони писались в умовах повоєнної недовіри радянського керівництва й органів безпеки до осіб, які пережили окупацію та побували за межами СРСР, а також, власне, страху громадян перед «системою». Через це у спогадах відсутня ціла низка аспектів повсякденного життя колишніх остарбайтерів на території Третього рейху, а основні зусилля авторів зосереджено лише на розкритті злочинів нацистських поневолювачів.

Ключові слова: остарбайтери, повоєнні спогади, трофейні документи, світлини, Миколаївщина, Третій рейх

Попри наявність значної кількості публікацій як українських, так і закордонних учених, на сучасному етапі в історичній науці ще триває процес залучення наративної інформації, регіональних комплексів джерел з метою всебічного дослідження мікроісторії мільйонів українців, які були депортовані на примусову працю до Третього рейху та його сателітів у роки Другої світової війни.

До одних з основних джерел, якими нині активно оперують дослідники, належать спогади колишніх примусових працівників, збір яких розпочався ще з середини 90-х років XX ст., й особливо активізувався після 2000-х років. Поштовх до формування даного виду джерел спричинив розпад СРСР і відновлення незалежності України, наявність законодавчих обмежень у використанні персональної інформації «остарбайтерів», що зберігалася у державних і галузевих архівних установах, діяльність міжнародних спеціалізованих фондів з виплати компенсацій потерпілим особам і відповідний суспільний резонанс та науковий інтерес, що виник у зв'язку з цим. У результаті маємо чимало наукових праць, в яких масово публікувались записані спогади людей ${ }^{1}$.

\footnotetext{
1 Пам'ять заради майбутнього: з історії десятирічної діяльності Української спілки в’язнів-жертв нацизму та спогади. Кн. 1 / Ред.-упоряд. О. Гаца й ін. Київ: КМЦ «Поезія», 2001. 563 с.; Пам'ять заради майбутнього: про діяльність Української спілки в'язнів-жертв нацизму та спогади. Кн. 2 / Ред.-упоряд. О. Гаца й ін. Київ, 2005. 763 с.; Пам'ять заради майбутнього: про діяльність Української спілки в'язнів-жертв нацизму та спогади. Кн. 3 / Заг. ред. М. Демидов. Київ: Фенікс, 2008. 464 с.; Невигадане. Усні історії остарбайтерів / Авт.-упоряд., ред., вступ. ст. Г.Г. Грінченко. Харків:
} 
Проте з поля зору більшості дослідників випали поодинокі унікальні колекції спогадів, що були створені в окремих областях ще у 1945-1946 роках і збереглись дотепер. У тематичних джерелознавчих дослідженнях регіонального характеру аналіз подібних корпусів документів, зібраних одразу після закінчення Другої світової війни, також не здійснювався². На Миколаївщині окремі їх фрагменти залучались місцевими істориками ${ }^{3}$ й архівістами ${ }^{4}$ до публікацій чи експонування в онлайнвиставках 5 , проте комплексне дослідження всього масиву даних матеріалів відсутнє.

Автор ставить за мету проаналізувати інформативний потенціал повоєнних спогадів колишніх примусових працівників Миколаївщини, висвітлити основні мікроісторичні сюжети повсякденного життя «остарбайтерів» та особливості даного корпусу історичних джерел.

Фонд Р-2083 «Колекція спогадів радянських громадян, які повернулись з німецько-фашистської каторги» Державного архіву Миколаївської містить спогади мешканців Арбузинського, Баштанського, Березнегуватського, Братського, Веселинівського, Володимирівського (нині не існує ${ }^{6}$ ), Вознесенського, Єланецького, Лисогірського (нині - Первомайського), Новобузького, Новоодеського, Очаківського, Привільнянського (нині - Баштанського), Снігурівського, Тилігуло-Березанського (нині - Березанського) районів Миколаївської області, що були написані у 1945-1946 рр. Загальна кількість спогадів даного фонду - 1146 одиниць, що становить 5,9\% від 19478 репатріантів, які повернулись станом на 1 квітня 1946 р.7

Оскільки ці спогади адресувались начальникам районних відділів НКВС, ймовірно, для цієї мети розсилались директивні вказівки у райони з переліком ключових питань, що мали бути висвітлені колишніми примусовими працівниками. Такі матеріали, вочевидь, мали бути додатковими свідченнями та доповнювати колекцію документів Державної комісії з розслідування злочинів нацистських окупантів.

Видавничий Дім «Райдер», 2004. 236 с.; Истерзанная юность: сборник воспоминаний. Николаев: Издательство Ирины Гудым, 2005. 112 с.; «...То була неволя». Спогади та листи остарбайтерів. Київ: Інститут історії України, 2006. 542 с.; «Прошу вас мене не забувати»: усні історії українських остарбайтерів / Гол. ред. Г. Грінченко; упоряд. І. Ястреб, Т. Пастушенко та ін. Харків: Право, 2009. 208 с.; Джерела пам'яті: Історико-краєзнавчий альманах. Вип. 2. Остарбайтери: жива правда живий біль / Упорядник Т.Ю. Нагайко. Переяслав-Хмельницький, 2010. 457 с.; Авраменко Ю., Каплюк В. Вони були остарбайтерами... / Sie waren Ostarbeiter...: розповіді колишніх бранців нацист. Німеччини з Переяславщини про їхнє перебування у Третьому рейху. Переяслав-Хмельницький: СКД, 2010. 255 с.; За гранью человечности. Судьбы остарбайтеров в дневниках и воспоминаниях / Сост. В.В. Чернявский, В.В. Животовская. Николаев: Илион, 2017. 220 с.

2 Меляков А.В. Масові джерела з історії депортації цивільного населення Харківщини до Німеччини в період 1941-1943 рр.: Дис.... канд. іст. наук: 07.00.06. Харків, 2003. 204 с.; Турчин Т.Р. Джерела до вивчення історії примусової праці та репатріації українців Станіславщини (1941-1953рр.): Дис... канд. іст. наук: 07.00.06. Івано-Франківськ, 2017. 254 с.; Мармілова О.С. Джерела до вивчення історії остарбайтерів з Донетччини: Дис.... канд. іст. наук: 07.00.06. Вінниця, 2018. 297 с.

3 Чернявский В.В. Под знаком «ОСТ»: остарбайтеры с юга Украины в Третьем рейхе и Румынии (1941-1956). Николаев: Илион, 2016. 272 с.

4 Медчук М. 3 листів та спогадів примусових робітників Третього рейху (за фондами Держархіву Миколаївської області) // Архіви України. Науково-практичний журнал. 2005. № 1-3 (256). С. 418425.

${ }^{5}$ Насильницьке вивезення мирного населення Миколаївщини на примусові роботи під час Великої Вітчизняної війни // Державний архів Миколаївської області: офіційна сторінка. URL: http://mk.archives.gov.ua/tematychni-rubriki/mwwii/142-onlinetogermany.html

6 Розформований і розподілений між Казанківським і Березнегуватським районами рішенням Миколаївського облвиконкому 22 січня 1959 р. - Прим. ред.

7 Державний архів Миколаївської області (далі - ДАМО). Ф. 992. Оп. 3. Спр. 75. Арк. 81. 
Аналіз текстів показує, що всі розповіді базувались навколо таких основних питань: 1. Автобіографічні дані, місце проживання та роботи до вивезення на примусову працю. 2. Місце роботи у Німеччині. 3. Умови життя у Німеччині. 4. Ставлення до радянських громадян з боку окупантів. 5. Опис випадків покарання (за наявності). 6. Коли й якими військами були звільнені. 7. Коли повернулись на Миколаївщину. 8. Актуальне місце роботи та адреса мешкання після повернення. 9. Дата написання спогадів. Основну мету створення досліджуваної колекції, фактично, сформульовано в описі до фонду: «...раскрыто зверский режим эксплуатации и насилия, существовавший в фашистской Германии, раскрыта радость освобождения советских людей и возвращения их на родную землю».

Післявоєнні соціально-політичні реалії, панування ідеологічної заангажованості у висвітленні подій німецько-радянської війни, директивний підхід до їх створення позначились як на сюжетних лініях персонального досвіду громадян, так і на розлогості їх спогадів. Через це частина спогадів написана досить детально (від 2-х до 10ти аркушів тексту), однак розкривають лише негативний досвід. Решта - написані формально, містять буквально два-три абзаци і переважно написані на клаптику паперу. Вочевидь, дехто обирав тактику максимально короткого інформування про свій різноманітний досвід примусової праці (не завжди травматичний) з метою уникнення подальших неприємностей у відносинах з владою та суспільством.

Здебільшого спогади містять автобіографічні дані (дата народження, освіта, місце роботи, місце мешкання), а також цікаву інформацію для дослідників історії українського селянства про соціально-економічне ставище авторів у довоєнний період. Найбільш важливими є фрагменти про колективізацію та Голодомор 1932-1933 pр., його демографічні наслідки для регіону. Документи містять як прямі, так і непрямі згадки про цей період. Автори переважно завуальовано описують, що у «1933 році ми з усією родиною переїхали на Донбас»8, або «батько (мати) померли у 1933 році»9 й ін. Так, Марія Ананіївна Ставенко була депортована із с. Любомирівка Березнегу-

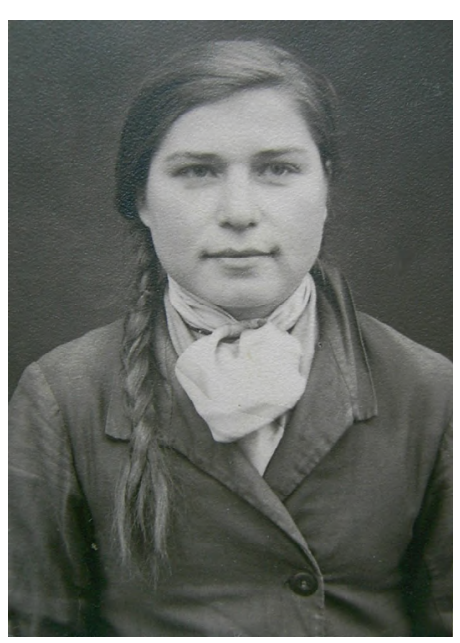

Фото 1. Н. Голокоз.

Польща, 1943 p.

(ДАМО.Ф. Р-2083. Оп. 1. Спр. 397) ватського району до Німеччини у 1944 р. Ї̈̈ короткі спогади є ілюстрацією про два десятиліття страшних мук і поневірянь, що випали на долю наших земляків у 30-ті - 40-ві роки XX ст. Ї̈̈ батько та дві старші сестри померли під час Голодомору в 1933 р., а мати була засуджена радянською владою того ж року за «п'ять колосків» на п'ять років. Марія Ананіївна залишалася на тривалий період одна у віці восьми років. По два тижні нічого не бачила та не їла, пухла від голоду і ледь сама не вмерла. Від 1933 р. постійно мучились і не бачила світлої години у свої молоді літа. То голод був і не мала змоги продовжити навчання, то потім почалась війна, згодом депортація до Німеччини ${ }^{10}$.

Деякі оповіді містять інформацію про початок окупації, першу реакцію населення на прихід окупантів, становлення «нового порядку». Надія Дмитрівна Голокоз згадувала, як 13 серпня 1941 р. об 11-й годині ра-

8 ДАМО. Ф. Р-2083. Оп. 1. Спр. 96. Арк. 1.

9 ДАМО. Ф. Р-2083. Оп. 1. Спр. 540. Арк. 26.

10 ДАМО. Ф. Р-2083. Оп. 1. Спр. 35. Арк. 2зв. 
дянські підрозділи ледве встигли виїхати із с. Червона Долина Снігурівського району, а вже о 15.00 до села зайшли німецькі війська. Населення розгубилося, з переляку не знало, що робити: дехто ховався у шанцях, у погребах, решта позакривались у хатах. Надія з мамою крадькома заглядали через затулене вікно на вулицю та спостерігали, як німецькі солдати ходили від хати до хати і незрозумілою мовою щось «белькотіли»11. До їх оселі теж навідались і почали грюкати у двері так, що аж засув відлетів, через що солдати утрьох разом упали до сіней хати та підняли сміх. На їх регіт прибігло ще два «фріци». Надія із сестрою сиділи нерухомо, а їх мати вийшла та запитала, що їм треба. Вони сказали: «матка, яйка, млеко, масла». Жінка відповіла, що нічого не має. Але вони згодом самі пішли нишпорити по коморах і, знайшовши молоко, пішли собі геть. На другий день вже стали люди потрохи ворушитись по хатах і виходити на вулицю. Через деякий час приїхав німецький представник. Було зібрано все населення. На зборах обрали старосту колгоспу та старосту сільської управи 12 .

Частина матеріалів відображає специфіку відбору кандидатів із сільських районів для роботи на території Третього рейху в 1942 р. До категорії «завербованих», у першу чергу, потрапляли представники багатодітних родин, повні сироти, прийшле населення з інших регіонів, безробітні, а також ті, хто просто не мав «потрібних» зв'язків. Кількість необхідних для роботи людей визначалась у районних комендатурах. Після отримання рознарядки місцеві старости сільських управ складали поіменні списки на власний розсуд ${ }^{13}$. Так, у червні 1942 р. з села Олексіївка Кривопустошківської сільради до Німеччини мали поїхати вісім чоловік ${ }^{14}$, з села Орлове Поле Братського району у вересні - чотири особи ${ }^{15}$, з села Новокостянтинівка Братського району у жовтні - 30 чоловік ${ }^{16}$.

Клавдія Чорна згадувала, що до серпня 1941 р. мешкала з родиною у м. Горлівка Сталінської області. Після довготривалих боїв у даному регіоні у місті почався голод, тож люди рятувати своє життя, тікаючи за межі міста. 5 листопада 1941 р. вся її родина вирішила повернутись на батьківщину до с. Лиса Гора Миколаївської області. Майже за місяць поневірянь пройшли пішки 800 км. Лише 1 січня 1942 р. дійшли до села. Були голодні та холодні, прийшли до села тільки у тому одязі, який носили 17. Дівчина одразу влаштувалась до колгоспу (кол. колгосп імені Молотова), де працювала до 1 жовтня 1942 р. 2 жовтня 1942 р. була направлена до Німеччини головою колгоспу Сухіним і старостою села Федоренком. Згадувала, що разом з нею під перші мобілізації потрапили вказані категорії людей. Проте молодь, яка мала захист, залишались вдома ${ }^{18}$.

Невиконання відробіткових норм, прогули на роботі, напружені міжособистісні побутові чи професійні стосунки часто теж ставали суттєвим фактором, який визначав подальшу долю місцевих мешканців. Неоніла Олексіївна Бець працювала у колгоспі «Новий побут», де бригадиром був Яків Манілов. Через те, що вона не мала можливості бути кожного дня на роботі, він заніс ії̈ у список людей, які не працювали та були призначені для відправки, та подав його до комендатури. Згодом її забрали до

11 ДАМО. Ф. Р-2083. Оп. 1. Спр. 397. Арк. 1.

12 ДАМО. Ф. Р-2083. Оп. 1. Спр. 397. Арк. 1зв.

13 ДАМО. Ф. Р-2083. Оп. 1. Спр. 535. Арк. 70зв.

14 ДАМО. Ф. Р-2083. Оп. 1. Спр. 533. Арк. 83.

15 ДАМО. Ф. Р-2083. Оп. 1. Спр. 533. Арк. 71.

16 ДАМО. Ф. Р-2083. Оп. 1. Спр. 533. Арк. 15.

17 ДАМО. Ф. Р-2083. Оп. 1. Спр. 535. Арк. 70.

18 ДАМО. Ф. Р-2083. Оп. 1. Спр. 535. Арк. 70зв. 
поліції. Прийшовши туди, побачила там коменданта Фігу і начальника поліції Петра Антонюка. На перший раз жінку посварили, призначили штраф у розмірі 50 рублів і відправили знову працювати у степ. Проте Яків Манілов ніяк не міг заспокоїтись і постійно доповідав Павлу Жуматію, який був у той час головою, що вона сама не працює та ще й других підбурює. Зрештою, її все ж занесли до списку кандидатів на другу мобілізацію. Викликавши її ввечері до колгоспної контори, повідомили, що на неї виписана повістка, тому наступного дня має поїхати до Німеччини. На обурення дівчини, Яків Манілов відповів: «А що, я пошлю ударниць, що працюють? Ось поїдеш, то хай тебе там навчать, як треба робити. Досить з книжечкою ходити вздовж вулиці»19. Вранці 2 жовтня 1942 р. під'їхала підвода, якою правив Іван Молдован і повезла дівчину до с. Благодатного. Коли проїжджали повз хату Якова Манілова, вийшла його дружина Анна, яка любувалась і сміялась з їі сліз. Неоніла Олексіївна піднялася з підводи та сказала їй, що вона її сльози побачить на своїх дітях. Та у відповідь крикнула: «Їдь, їдь, суко, щоб ти туди не доїхала, а назад не повернулась»20.

Злочини більшовицької влади під час суцільної колективізації сільського господарства, зубожіння та позбавлення прав українського селянства, Голодоморгеноцид 1932-1933 рр., масові політичні репресії 20-х - 30-х років XX ст. теж наклали свій політичний відбиток на міжлюдські відносини, сприяли поширенню колабораціонізму під час нацистської окупації краю, ставали визначальним фактором для відбору перших кандидатів на депортацію до Німеччини, якщо їм пощастило до того якимсь дивом уникнути арешту поліцією безпеки та СД. Частина постраждалих від політики радянської влади громадян активно йшла служити на посади в окупаційні адміністрації, місцеву поліцію, мстили членам комуністичної партії та їх родинам, виселяли зі своїх колишніх будинків радянських активістів, які поселялись туди після розкуркулювання та виселення з домівок справжніх господарів.

Одним із прикладів може стати той факт, що під час нацистської окупації до Гребенниківської сільради Новоодеського району на своє попереднє місце мешкання повернувся Іван Дабіжа, якого радянська влада пограбувала під час розкуркулення та вигнала з власної домівки ще на початку 30-х років XX ст. Ставши старостою місцевої сільської управи, до списку першочергових кандидатів на відправку до Німеччини призначав людей, враховуючи попередні «заслуги»21. Так, Марія Резніченко 3 с. Гребінники була депортована 5 вересня 1942 р. через те, що була дружиною партійного працівника. Працювала на фабриці у Ганновері22. Схожа ситуація простежується і в інших населених пунктах. Іван Семенович Коломійко 20 жовтня 1942 р. був депортований на примусову працю до німецького міста Веттер (Wetter), що розташовувалось у Рурському промисловому районі. Під час окупації йому згадали те, що він у 1930 р. брав участь у розкуркулюванні населення та працював фінагентом, у 1931 р. став членом правління колгоспу й активно брав участь у всіх політичних кампаніях радянської влади 23.

На жаль, дані джерела абсолютно не висвітлюють діяльність німецької пропаганди з вербування населення на роботу до Третього рейху, зміст наочної чи усної агітації, кадровий склад пропагандистських делегацій до сільських районів, як і, влас-

\footnotetext{
19 ДАМО. Ф. Р-2083. Оп. 1. Спр. 535. Арк. 6.

20 ДАМО. Ф. Р-2083. Оп. 1. Спр. 535. Арк. 6зв.

21 ДАМО. Ф. Р-2083. Оп. 1. Спр. 537. Арк. 40.

22 ДАМО. Ф. Р-2083. Оп. 1. Спр. 537. Арк. 46.

23 ДАМО. Ф. Р-2083. Оп. 1. Спр. 537. Арк. 30.
} 
не, ефективність її впливу на населення. Окремі дані містять скупу інформацію, що процедура спілкування представників місцевих органів влади з визначеними особами для «добровільного виїзду» на роботу до Німеччини була нетривалою. Як згадував Василь Шевченко, 18 червня 1942 р. староста села Гречанівка Снігурівського району Ф.Т. Саприкін приніс йому документ, в якому потрібно було розписатись, що той прийде до сільуправи для запису на роботу до Німеччини. У визначений день він пішов туди з товаришем, де на місці їх зустрів голова сільуправи Роман Холодар, німецький жандарм і перекладач. Роман Холодар звернувся спочатку до Якова Самійленка та запитав, чи поїде той на роботу на шість місяців до Німеччини. Яків Самійленко відповів, що не має такого наміру. Тоді Р. Холодарь звернувся до перекладача і каже: «Пиши Самійленка. Він поїде, що ми з ним будемо гратись». Розмова з Василем Шевченком теж була короткою. Йому заявили, чи бажає він чи ні, але до Німеччини все одно поїде 24 .

Незважаючи на певні недоліки, викликані впливом політичної кон'юнктури, позивним моментом $\epsilon$ те, що ці джерела представлені масово, охоплюють спогади мешканців одного району чи населеного пункту, осіб певної вікової категорії, яких одночасно депортували до Третього рейху у той чи інший визначений період у 19421944 рр. Виявлені дані дозволяють з'ясувати прізвища представників місцевих адміністрацій, поліції, локалізувати місця і процес проходження медичних комісій, станції відправки, маршрути, умови та тривалість подорожей до місць розподілу та роботи, особливості повсякдення під час примусової праці й ін.

Більшість «остарбайтерів» наголошували, що місцеві медичні огляди були досить формальними, тому їх сподівання залишитись вдома через реально слабке здоров'я чи симуляцію захворювання виявились марними. Лікарі звертали увагу тільки на серйозні хвороби: короста, туберкульоз, тиф, вагітність чи тяжку інвалідність. На дрібні пошкодження не реагували. Сорока Віра Микитівна 27 серпня 1943 р. проходила «медкомісію» в Арбузинці у школі № 125. Описувала цей процес так: «Це тільки називався медогляд. Лікарі не оглядали нас, а тільки насміхались. Вони називали нас брехунами, коли ми говорили, що хворі. Брали з наших рук повістки і відзначали, що «пройшла», «провірена». Згадувала, що коли ввійшла до кімнати, її запитали: «Ти себе почуваєш хворою?». Вона відповіла, що так, вона хвора. Їй наказали роздягтись. Коли вона зробила це, з неї почали насміхатись лікарі... Вона повідомила, що хвора на серце і розплакалась. Проте їі вигнали у другу кімнату, де сиділи машиністки, які записували персональні дані “придатних"»26. Після завершення медогляду молодих людей зачинили у приміщенні школи, не випускали у двір, де грав духовий оркестр. Скрізь стояли поліцаї. На територію школи не допускали навіть батьків ${ }^{27}$. Як згадував Григорій Саєнко, у той день з «комісії» відпустили б лише у тому випадку, якби хтось був без голови: каліки, хворі, здорові - всі пройшли медогляд, справно одержавши напис на документі «gesund» (здоровий). Додому звідти більше нікого не відпустили. Ніч перед відправкою проводили там же на підлозі28.

Надія Мацюра з села Новопетрівське Новодеського району у серпні 1943 р. під конвоєм була доставлена на збірний пункт, що знаходився в Миколаєві у будівлі

\footnotetext{
24 ДАМО. Ф. Р-2083. Оп. 1. Спр. 523. Арк. 1.

25 ДАМО. Ф. Р-2083. Оп. 1. Спр. 529. Арк. 50.

26 ДАМО. Ф. Р-2083. Оп. 1. Спр. 529. Арк. 50зв.

27 ДАМО. Ф. Р-2083. Оп. 1. Спр. 6. Арк. 1зв.

28 ДАМО. Ф. Р-2083. Оп. 1. Спр. 21. Арк. 1.
} 
Спиртзаводу. Разом зі своєю подругою пили міцний чай, робили опіки на руках, щоб було схоже на коросту, натирали очі цибулею й ін. У той час вони всі ходили «як дурні». Але на комісії їх визнали придатними. На рани не дивились, а дивились на особистість. Тих, хто подобався членам комісії, визнавали непрацездатними. А так брали усіх підряд 29.

До деяких маніпуляцій під час медогляду вдавались і батьки, які мали декількох дітей. Проте за тих умов відбору, що практикувались, на примусову працю потрапляли навіть неповнолітні підлітки. Тринадцятирічний Яків Юхименко з с. Крива Пустош Братського району теж «пройшов медогляд». У серпні 1943 р. він був депортований до Німеччини замість своєї старшої сестри 1926 р. народження, яка підпадала під мобілізацію. На думку Якова Юхименка, це трапилось через те, що його батьки сподівались, що його не візьмуть на роботу через його вік ${ }^{30}$.

Однією із сюжетних ліній спогадів є опис процесу відправки на залізничні станції, драматичну реакцію батьків на від'їзд їх дітей у невідомий край, довготривалі поневіряння дорогою в умовах поганого харчування, повного дискомфорту й антисанітарії у вагонах, безкінечні медогляди у таборах-розподільниках. Любов Панченко 25 вересня 1942 р. із земляками пройшла «медкомісію» у Снігурівці. Додому вже нікого не відпускали. Ночували у клубі «Червоний Жовтень», що охоронявся німецькою поліцією. Наступного дня людей повезли у набитих вагонах до Миколаєва, де розмістили у школі № 4 (Спиртзавод). Там пробули ще десять днів. Харчування отримували два рази на день: «...півлітри води і де-не-де якась крупинка...». Коли людей повели на залізничний вокзал, то там зчинився неймовірний крик і плач батьків. Дорогою до Перемишля везли у товарних вагонах. 3 харчування отримували лише кружку «баланди». Там була наступна медкомісія, баня. Хто не встигав одягтися після бані, то отримував одразу удар батогом. Ночували у холодних і брудних бараках, обтягнутих колючим дротом. Спали на дерев'яних нарах без будь-якої постільної білизни упродовж двох ночей. Змучених людей, які отримали по 4 кг хліба на п'ятьох осіб, в ешелонах повезли далі до м. Розенберг, де була чергова медкомісія та розподіл по роботах ${ }^{31}$.

Варто звернути увагу на деякі деталі, які ускладнювали ситуацію як під час руху залізницею до місць роботи на території Третього рейху, так їх становище під час перших місяців роботи. Люди згадували, що уповноважені особи сільської адміністрації попереджали людей перед виїздом на роботу до Німеччини, що там їх забезпечать усім необхідним, тому з дому не варто брати багато «тряпок», бо на кордоні їх все одно заберуть, оскільки вони там непотрібні ${ }^{32}$. Люди мали взяти лише змінний одяг на декілька днів і так само їжі. Колишні примусові працівники нарікали, що у транзитних таборах під час термообробки («прожарки») їх одягу, він фактично втрачав вигляд і був непридатним для подальшого вжитку 33 . Оскільки не всі остарбайтери могли купити нормальний одяг з різних причин (мізерна зарплатня, високі ціни на одяг, карткова система у Німеччині), в умовах мінімального забезпечення робочим одягом і взуттям на підприємствах (часто - відсутнього навіть такого), люди ходили на роботу буквально «босі та обірвані» тривалий час. Це продовжувалось

\footnotetext{
29 ДАМО. Ф. Р-2083. Оп. 1. Спр. 537. Арк. 38.

30 ДАМО. Ф. Р-2083. Оп. 1. Спр. 533. Арк. 100.

31 ДАМО. Ф. Р-2083. Оп. 1. Спр. 540. Арк. 51.

32 ДАМО. Ф. Р-2083. Оп. 1. Спр. 540. Арк. 86.

33 ДАМО. Ф. Р-2083. Оп. 1. Спр. 540. Арк. 86зв.
} 
доти, поки вони не отримували у посилках з дому якийсь більш-менш придатний одяг, діставали його через бартер чи в інший спосіб на місці.

Згідно вищезгаданих розпоряджень люди брали з собою запас домашньої їжі лише на декілька днів. Оскільки за час перебування на збірних пунктах чи під час тривалого переїзду залізницею запас продуктів швидко вичерпувався, а той «раціон», що пропонували людям у дорозі, був малокалорійним чи просто непридатним до вжитку, тому молодь потерпала також і від недоїдання та спраги. Григорій Саєнко згадував один випадок, що трапився з ним і його земляками. У вересні 1943 р., коли ешелон вирушив з транзитного табору у Львові та перетнув польський кордон, потяг зупинився на першій станції. Там надумали дати їм гарячого супу, що складався 3 нечищеної картоплі, води та капусти. Люди одержали цей «суп» у паперових мисках. Не пройшло і півгодини, як паперові тарілки разом із «супом» обліпили весь перон, вагон і будинки. За це усіх позаганяли назад у вагони та позачиняли. Було душно, бо у вагоні знаходилось 45 чоловік зі своїм багажем, тому не було навіть місця де сісти. Хотілось пити. Не звикши таке терпіти, усі почали стукати, свистіти, кричати. Вагон відкрили та запитали, чого вони хочуть. Люди відповіли, що хочуть пити і просять, щоб їх не зачиняли. П’ятьох пустили по воду, але, коли вони повернулись, кожний 3 них отримав удар гумовою палицею, залазячи до вагону. Їх знову зачинили, і потяг поїхав далі 34 .

У багатьох українців до проходження основної медкомісії у розподільчих таборах у Перемишлі, Бреслау й інших містах ще жевріла примарна надія, що, можливо, звідти їм вдасться повернутись додому. Дорогою туди або безпосередньо у таборі намагались завдати собі помітних травм: на ніч прикладали до тіла чи між пальці рук часник або сіль ${ }^{35}$, били себе кропивою, мазали очі й ін. Через це виникали опіки ${ }^{36}$. На нашу думку, це не давало бажаного результату, а навпаки ще й ускладнювало подальше становище з декількох причин. По-перше, до таких симуляцій лікарі відповідних комісій були готові. По-друге, через завдані собі травми люди потерпали від значного дискомфорту під час тривалого переїзду, втрачали «презентабельний» зовнішній вигляд і можливість отримати «чисту» роботу. По-третє, якщо когось і залишали на певний час у лазареті транзитного табору, вони відставали від своїх земляків і втрачали можливість потрапити разом на роботу та підтримки один одного у майбутньому. По-четверте, через умисне завдання собі шкоди дехто втрачав здоров'я на все подальше життя. Так, Катерина Боровик у розподільчому таборі у Перемишлі «курила» чай, щоб уникнути роботи у Німеччині. Її задум не вдався, але через це вона навіть після війни залишалась хвора на серце ${ }^{37}$.

У 1943 р. населення було депортоване на примусову роботу до Німеччини шляхом явного обману. Так, 27 серпня 1943 р. частина населення Арбузинки отримала повістки для мобілізації молоді нібито на роботу до Києва на шість місяців. Після відбуття повинності мали повернутись додому. Наступного дня люди мали з'явитись на залізничну станцію Кавуни о 14.00 із власними продуктами та постільною білизною. Звідти людей завантажили у вагони та повезли до Вознесенська, де пробули до 20.00. Людей порахували, видали по 1 кг просяного хліба, завантажили у

\footnotetext{
34 ДАМО. Ф. Р-2083. Оп. 1. Спр. 21. Арк. 2.

35 ДАМО. Ф. Р-2083. Оп. 1. Спр. 531. Арк. 35.

36 ДАМО. Ф. Р-2083. Оп. 1. Спр. 529. Арк. 46зв.

37 ДАМО. Ф. Р-2083. Оп. 1. Спр. 530. Арк. 19.
} 
потяг і повезли знову на ст. Кавуни ${ }^{38}$, а звідти - на ст. Помічна. Переночували там у якійсь будівлі, і знову дорога у напрямку Києва. Там була коротка зупинка, під час якої додали ще вагони з місцевим людом, та всіх одразу повезли прямо до Перемишля 39.

Масовими пастками для людей ставали і колективні роботи з ремонту автошляхів, залізничних колій, риття шанців тощо. Михайло Мазуренко із с. Новокрасне Лисогірського району з весни 1943 р. виконував відновлювальні роботи на автодорогах. 27 липня 1943 р. всю молодь 1926 р. народження терміново викликали на ст. Помічна для нібито ремонту залізничної колії. Коли прибули на місце, поліція їх завела до клубу, в якому перебувало повно людей. Вночі всіх завантажили у вагони та повезли, не давши можливості попрощатись з рідними. Через вісім діб вже прибули до м. Кельн у транзитний табір. Згодом потрапив до м. Крефенброх у табір для східних працівників, де працював на залізниці у нелюдських умовах 40 .

Деякі колишні примусові працівники описували не лише побутові умови мешкання у тих таборах, в яких вони працювали. Їх спогади містять важливі деталі, що дають уявлення про зовнішній вигляд таборів-розподільників, умови перебування там населення. Іван Іванович Сімкін у вересні 1943 р. разом із молоддю із Снігурівського району потрапив до пересильного табору у Бреслау (нині - Вроцлав). На його території розміщувалось 50 бараків, що були обнесені забором із колючим дротом заввишки 2,5 м. Крім пересильного, там були й табори для тяжкохворих туберкульозом, поранених на заводах, калік. Іван Іванович пробув там два дні. На власні очі бачив, як кожного ранку виносили трупи голих людей, звалювали у спеціальні машини та кудись вивозили 41.

Чимало колишніх примусових працівників пригадувало, що дорогою до Німеччини міркували про втечу з потяга та повернення додому чи ставали свідками вдалої втечі своїх земляків. Такі рішення були імпульсивними та непродуманими, до того ж ставали фатальними або ж ускладнювали подальше становище для людини, яка вдавалася до цього з декількох причин. По-перше, кожен вагон охоронявся і внаслідок спроби втечі людей стріляли одразу на місці. По-друге, навіть вдала втеча, переховування певний час, не гарантували порятунок від депортації, уникнення відповідальності у майбутньому без наявності відповідних документів. Крім того, такі вчинки наражали на небезпеку і родину такої особи.

Наведемо для прикладу історію Дар'ї Михайлівни Ритик, яка у 1943 р. під час загальної мобілізації молоді із с. Зелений Клин була вивезена разом з односельцями на залізничну станцію Явкине. Доїхавши до ст. Знам'янка, вона зуміла втекти. Дорогою зустріла ще одну дівчину, з якою разом почали рухатись додому у Баштанський район. Йшли пішки глухими місцями аж до залізничної станції Казанка ${ }^{42}$. Звідти добрались до с. Гаражино, куди приїхали о 12-й ночі. Деякий час переховувалась у соняшниках і кукурудзяних полях біля села. Прийшовши до рідної хати, вона почула розповідь матері, що у колгоспі були збори, і староста Михайло Ткачов повідомив людям, що якщо хтось 3 тих, хто мав їхати до Німеччини, залишився вдома, то необхідно негайно повідомити, бо буде ще гірше. Дарія Михайлівна переховувалась вдо-

\footnotetext{
38 ДАМО. Ф. Р-2083. Оп. 1. Спр. 529. Арк. 35.

39 ДАМО. Ф. Р-2083. Оп. 1. Спр. 529. Арк. 35зв.

40 ДАМО. Ф. Р-2083. Оп. 1. Спр. 535. Арк. 37.

41 ДАМО. Ф. Р-2083. Оп. 1. Спр. 540. Арк. 63.

42 ДАМО. Ф. Р-2083. Оп. 1. Спр. 532. Арк. 13.
} 
ма 2,5 тижні. Згодом Ольга Глущенко, яка слідкувала за їх хатою, видала її, повідомивши старосту села, що вона переховується у себе вдома ${ }^{43}$. Вночі її заарештували та повезли спочатку до Баштанської, а потім до Новобузької тюрми, де її допитували про причини втечі. Зрештою, її все ж відправили на роботу до Австрії під час наступної мобілізації молоді44.

Основний акцент у власних спогадах мешканці Миколаївщини робили на висвітленні умов злиденного життя та важкої праці на численних об'єктах військовопромислового комплексу чи роботи у приватних садибах своїх господарів. Важливі складові їх оповідей - тривалість і місце роботи, харчування, умови проживання у таборах, радість звільнення. «Класичне» повсякдення українських примусових працівників можна простежити на прикладі спогадів Ольги Ілляшенко, яка з вересня 1943 р. працювала на заводі чорноробом у німецькому селі Зинн. Робочий день тривав 12-ть годин: з 7-ї ранку до 7-ї вечора. Обідня перерва - менше години. Часто працювали у дві зміни. Робота була брудна і тяжка. Через недостатнє харчування ця непосильна праця здавалася ще тяжчою. Східні робітники отримували встановлений для такої категорії іноземних працівників пайок: 200-300 г хліба, два рази приварок (суп з капусти чи брукви), вранці лише кава. У неробочий чи вихідний день українці отримували їжу лише раз на день (тільки в обід). У додаток до цього люди ще отримували 100 г маргарину, 100 г цукру на тиждень. Бували випадки, що зовсім лишали без шматка хліба через якусь провину (через запізнення на роботу чи довгу прогулянку у вільний час).

За вихідцями з СРСР суворо наглядала поліція. Остарбайтери не мали права виходити на вулицю у зимовий час після 19.00 вечора, а у літній період - після 22-ї години. Під час спільної роботи з іноземцями чи навіть з земляками іншої статі заборонялось розмовляти. У вихідний день чи у вільний час люди не мали права виходити за межі населеного пункту. Без дозволу начальника поліції примусові працівники не могли провідати своїх земляків чи знайомих в інших населених пунктах чи фабриках. За запізнення на роботу після бойової тривоги - садили у підвал. За порушення чи невиконання встановленого режиму садили до концтабору. Суворо заборонялося виходити на вулицю без знака розрізнення національностей ${ }^{45}$. За відсутності «OSTa» на перший раз накладався штраф до 50 марок, а випадку повторення - садили у тюрму46. Дехто з примусових працівниць розшифровували «Ost» як «Остерігайтеся совєцьких товаришів» 47.

На фізичне та психологічне виснаження людей також впливали і табірні умови їх утримання. Більшість описує «стандартний побутовий комфорт», що мали примусові працівники зі Сходу у бараках. Марія Іванівна Хілєва у жовтні 1942 р. потрапила до табору м. Штуттгарта, в якому нараховувалось 1500 «російських» дівчат. Спочатку вона працювала на фабриці «Вosch». Потім її у складі 20 дівчат вивезли на відстань понад 100 км від Штуттгарта у село Тіфлінген. Там працювала на відомій трикотажній фабриці «Конрад Майер» (сучасний концерн «Комацо», що виробляє найвідомішу у Німеччині термо- та нижню білизну). Працювали по 12 годин. Мешкали на території розваленої фабрики, де було 180 дівчат. Мали по дві ковдри та спали на де-

\footnotetext{
43 ДАМО. Ф. Р-2083. Оп. 1. Спр. 532. Арк. 13зв.

44 ДАМО. Ф. Р-2083. Оп. 1. Спр. 532. Арк. 14.

45 ДАМО. Ф. Р-2083. Оп. 1. Спр. 541. Арк. 28.

46 ДАМО. Ф. Р-2083. Оп. 1. Спр. 5. Арк. 2.

47 ДАМО. Ф. Р-2083. Оп. 1. Спр. 334. Арк. 1зв.
} 
рев’яних ліжках з матрацами, набитих соломою. Така постільна білизна кишіла клопами, що постійно не давали людям спати. Бараки не опалювались, бо остарбайтерам не видавали вугілля. У дерев'яному таборі вони не жили, а мучилися, оскільки взимку було холодно. Жінки мусили ходили красти у німців, щоб мати змогу обігріти свої бараки. Німці дивились на них як на тварин, називали «руськими свинями»48.

Працюючи на різних підприємствах, українці чітко помічали різницю в ієрархії цивільних іноземних працівників на території Третього рейху: у найгіршому становищі перебували саме «остарбайтери». Інколи примусовим працівникам з України вдавалось покращити свої умови роботи та харчування. Дуся Семенівна Клічановська згадувала, що під час роботи у Бреслау, спочатку умови роботи були погані. Проте їх становище поліпшилось, коли у жовтні 1944 р. їх у кількості 12 чол. перевели на якусь воєнну фабрику, де працювали переважно поляки та чехи. Оскільки «остарбайтерів», які там працювали, було небагато, то харчування вони отримували таке ж, як решта іноземних працівників ${ }^{49}$.

Постійне почуття голоду змушувало частину примусових працівників, реально ризикуючи власним життям, красти продукти харчування у своїх «господарів». Як не парадоксально, особлива нагода траплялася під час авіабомбардувань населених пунктів чи підприємств. Семен Бойченко з Баштанки так і розповідав: «...Коли почались масові бомбардування міст, нам стало трохи краще. Німці тікали у бомбосховища, а «росіяни» бігли за здобиччю щоб що-небудь взяти поїсти, не зважаючи на загрозу життю»50. А. Баранюк умудрився під час авіанальоту вкрасти хлібні картки 3 магазину у якогось австрійця - каптілку із салом і м'ясом та приніс хлопцям до бараку51.

Зрозуміло, що тих, хто попадався на крадіжках, карали побиттям, садили у штрафтабори, страчували. Бей Дмитро згадував, що в їхньому таборі за крадіжки продуктів харчування у німецького населення під час повітряної тривоги, охорона карала на смерть: 10-15 чоловік розстрілювали, а їх тіла залишали на перехресті, які лежали там 5-6 днів ${ }^{52}$.

У непростих умовах повсякденного життя в умовах примусової праці на чужині перебували й подружні пари. Наявність близької людини, з одного боку, дозволяла переживати життєві негаразди разом, з іншого - такі люди ставали заручниками певних обставин, через які їх становище значно ускладнювалось. Олександра Іллівна Маламан у червні 1942 р. із с. Михайлівка Новоодеського району була депортована до Німеччини. Працювала у приватному господарстві. Згодом у неї з чоловіком народилася дитина. Така ситуація не влаштовувала німецького господаря, який захотів віддати дитину до табору. Олександра Маламан з чоловіком не дозволили це зробити. Через таку категоричну позицію подружжя чоловіка забрали до поліції, а їі саму побив господар. Дитину вони відстояли, проте всю родину направили працювати до іншої приватної садиби в одне село поблизу Гамбурга53. Ставлення до української родини й умови у нового господаря були не кращі. Олександра Іллівна брала дитину з собою, коли ходила на роботу у степ. Чоловіка згодом забрали на риття

\footnotetext{
48 ДАМО. Ф. Р-2083. Оп. 1. Спр. 529. Арк. 64.

49 ДАМО. Ф. Р-2083. Оп. 1. Спр. 540. Арк. 29.

50 ДАМО. Ф. Р-2083. Оп. 1. Спр. 530. Арк. 16.

51 ДАМО. Ф. Р-2083. Оп. 1. Спр. 537. Арк. 2-3.

52 ДАМО. Ф. Р-2083. Оп. 1. Спр. 2. Арк. 1зв.

53 ДАМО. Ф. Р-2083. Оп. 1. Спр. 537. Арк. 37.
} 
шанців. Під час спроби втечі та намагання повернутись до дружити й дитини він був поранений німецькою поліцією. Через поранення пролежав у госпіталі аж до звільнення союзними військами 54 .

У спогадах можна віднайти цікаві дані про те, як відбувалося цензурування листів з України, що надходили до примусових працівників, які трудилися у німецьких приватних оселях. Олена Фіщенко у 1943 р. із с. Лиса Гора потрапила на роботу до великого приватного господарства Петера Брайбаха, який мешкав на хуторі Зітлюнг поблизу м. Кобленца. Коли надходили листи з дому на ім'я Олени, то вони, ясна річ, спочатку потрапляли до рук німецької господині. Потім вона їхала у найближче село, що знаходилося на відстані 4 км від хутора, заносила ті листи до місцевого відділу поліції, де їх перечитував перекладач. Лише після цього німкеня заспокоювалася. Бувало так, що господиня отримувала листа Олени та не віддавала цілий тиждень, а потім кидала їй, кажучи, що нібито щойно надійшов 55 .

Низка документів містять перші обережні згадки, які не вписувалась у рамки загальноприйнятої концепції, що панувала згодом у радянській історіографії, про винятково негативний досвід примусової праці. Окремі колишні примусові працівники коротко описували більш-менш нормальні умови роботи, харчування та ставлення до них з боку керівництва підприємств чи членів родин, у приватних садибах яких вони працювали. Ніна Ігнатівна Даленко була вивезена до Австрії у березні 1943 р. Потрапила на роботу до м. Кніттельфельд, що розташоване у відомому гірськолижному курортному регіоні. Пригадувала, що господар Томас Лайтолт, у якого вона працювала, ставився до неї добре, не бив та ін. ${ }^{56}$ Надія Слісаренко у серпні 1943 р. 3 села Воєводське Лисогріського району потрапила до Німеччини та працювала у селі Обервіль на овочевій консервній фабриці. Сама робота була легкою, проте годували погано, нікуди не випускали та шеф був злим. Проте через два місяці їі перевели працювати на завод «Роберт Клинк Ветцлар», що виготовляв шарикопідшипники для літаків. Попри тяжку роботу, там годували непогано, і начальник був нормальний, добре ставився до «руського народу» 57.

Документи свідчать, що статус примусового працівника можна було досить легко втратити за найменшої провини та потрапити з трудових таборів до тюрем гестапо, штрафтаборів, де люди були позбавлені будь-яких прав. У «найлегшому» варіанті після допитів і тортур люди потрапляли у карцери чи штрафтабори, де потерпали упродовж декількох тижнів чи місяців, а після цього виснажені все ж повертались до роботи. Так, Григорій Олександрович Саєнко у вересні 1943 р. із десятьма земляками потрапив працювати на цукрову фабрику, що розташовувалась біля села Аллерінгерслебен (Саксонія-Анхальт). Працювала вона лише три місяці на рік. Решту часу ремонтували та чистили машини, труби, печі, котли, вантажили камінь, пісок, цеглу, вугілля, загалом виконували брудну та важку роботу58. Коли закінчився перший сезон, то шість чоловік з його бригади відправили працювати до іншого міста.

Одного разу Григорій Саєнко з хлопцями одержав від своїх земляків, які від'їхали до Магдебургу, листа, де вони повідомляли, що потрапили у ще більш скрутніші умови, тому просили зібрати 1 кг цукру та вислати їм поштою. Григорій Саєнко 3

\footnotetext{
54 ДАМО. Ф. Р-2083. Оп. 1. Спр. 537. Арк. 37зв.

55 ДАМО. Ф. Р-2083. Оп. 1. Спр. 535. Арк. 66-67.

56 ДАМО. Ф. Р-2083. Оп. 1. Спр. 535. Арк. 18.

57 ДАМО. Ф. Р-2083. Оп. 1. Спр. 535. Арк. 58зв.

58 ДАМО. Ф. Р-2083. Оп. 1. Спр. 21. Арк. 3-Ззв.
} 
друзями не відмовили. За декілька днів цукор зібрали та запечатали. Треба було лише переслати. Надсилати посилки з харчовими продуктами заборонялось, тому кожний з них боявся здавати посилку на пошту. Нарешті Григорій Саєнко насмілився і власноруч відніс цукор на поштове відділення. На перший погляд здалося, що все добре: посилку оформили, а він розписався у документах 59 . Через декілька днів його викликали до бюро. За спробу допомогти товаришам, які потребували допомоги, йому присудили два тижні штрафтабору і 50 марок штрафу. Там Григорій Саєнко дійсно зрозумів, що таке німецька нагайка, тому надовго запам'ятав цей досвід. Після відбуття покарання повернувся знову на фабрику i, завжди голодний та обірваний, продовжував тяжко працювати 60.

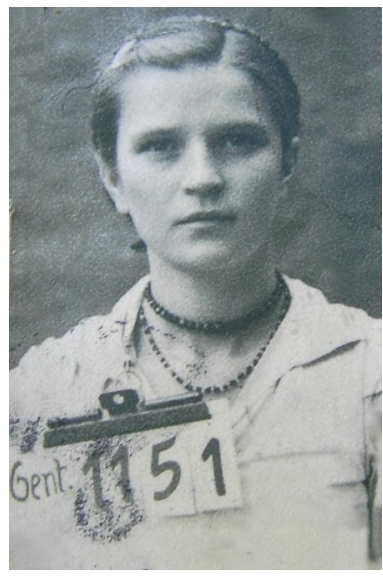

Фото 2. Раїса Макаренко. (ДАМО. Ф.Р-2083. Оп. 1. Спр. 529)

У найгіршому варіанті - людей страчували чи відправляли до концтаборів, де шанси звичайного в'язня вижити зводились до мінімальних. Раїса Михайлівна Макаренко працювала у німецькому місті Бург. Через нестерпні умови роботи втекла від свого господаря. Ї̈̈ зловили та посадили у тюрму гестапо у Магдебурзі, потім перевели до тюрми у м. Дрезден. Під час допитів ї̈ зарахували до категорії «комуністка» та відправили до концтабору Аушвіц. Мала табірний номер 82344. Раїса Михайлівна згадувала, що кожного дня бачила «...костер, пламя которого пожирало тысячи людей, я слыхала крики детей, матерей, стариков, я видела как умирают голодной смертью»61. Згодом була переведена до концтабору Маутхаузен. Загалом перебувала у концтаборах з 20 травня 1944 р. по 5 травня 1945 р.62

Такі спогади є надзвичайно важливими, оскільки відображають не тільки особливості примусової праці конкретного «остарбайтера», але одночасно містять свідчення про нацистські злочини у концтаборах людини, якій вдалось вижити. Євдокія Воротинцева була депортована на роботу до Польщі з м. Новий Буг у серпні 1943 р. Працювала у приватному господарстві у польському місті Крауденц (польск. Grudziądz aвm.). 21 липня 1944 р. Євдокію Воротинцеву та її подругу Ольгу Черкасенко було заарештовано та відправлено до тюрми за те, що вони склали вірш і написали листа політичного змісту. Як з'ясувалось, дівчата передали це повідомлення поляку, який їхав в Україну, з проханням, щоб він кинув його у поштову скриньку в Україні. Лист був написаний 8 січня 1944 р., а вже у липні 1944 р. потрапив до гестапо. У тюрмі просиділи один місяць. Ольгу Черкасенко відпустили, а Євдокію Воротинцеву із міста Крауденц на «чорному вороні» відвезли до тюрми у м. Данциг. Потім у спеціальних вагонах для в’язнів відвезли до міста Штеттін. Там вона просиділа у тюрмі ще три місяці. Згодом потрапила у концтабір Равенсбрюк неподалік від Берліна (у тексті Ровензберг - aвm.), де на той час знаходилось 73000 бранців з терміном ув'язнення «до закінчення війни». Ставлення до в'язнів було нелюдське. Раз на день бранці отримували суп з брукви, шпинат і 200 г хліба. Щоденний підйом був о 3-й годині ранку. Всіх виганяли з бараків у двір, який був огороджений кам'яним муром

\footnotetext{
59 ДАМО. Ф. Р-2083. Оп. 1. Спр. 21. Арк. Ззв.

60 ДАМО. Ф. Р-2083. Оп. 1. Спр. 21. Арк. 4.

61 ДАМО. Ф. Р-2083. Оп. 1. Спр. 529. Арк. 29.

62 ДАМО. Ф. Р-5859. Оп. 1. Спр. 13325. Арк. 4, 8.
} 
висотою 12 м і знаходився під електричною напругою. Табір охороняли війська SS. Над жінками знущались у різні способи: били, обливали холодною водою, змушували стояли на морозі на апельплаці з 3-х годин ночі упродовж 10-ти годин поспіль в одних тонких робах, на яких були вишиті чорні хрести. Часто таке покарання тривало упродовж цілої доби. У цьому таборі був крематорій, де спалювали живих людей.

У концтаборі Равенсбрюк Євдокія Воротинцева просиділа з 1944 р. і до початку 1945 р. У січні 1945 р. її відправили до концтабору у м. Магдебург. Там вона працювала на військовій фабриці «Польте» (йдеться про «Polte-Werke» - авт.). Робочий день тривав по 12-ть годин. Харчування отримували те ж саме. Підйом був о 3-й годині ночі. Перевірка в'язнів на апельплаці тривала до 6-ї ранку. Потім під конвоєм солдатів SS бранців вели працювати на завод. 018 годині вечора їх приводили з фабрики до табору, де знову стояли на апельплаці до 22 години, очікуючи, поки охоронці табору всіх перерахують 63.

Нижче наводиться вірш (українською мовою) та пісня (російською мовою), за написання яких Євдокія Воротинцева потрапила до вказаних концтаборів:

Горить лампадка в хаті тихо Сімя спокійно уся спить, А мати з горічка й досади Сама зажурена сидить.

Сидить вона і все сумує I гіркі сльози пролива, Вже десять місяців минає Моєї дочічки нема.

Нема її може й небуде Може живої вже нема, Мені ніхто слова не скаже Я її ждатиму щодня.

А утром встану де не гляну

Куди не вийду все сама, Дівчатка людські усі дома Моєї дочечки нема.

Ой, доня моя рідна

Яка нещасна в світі ти, Зазнаєш горічка й досади Серед проклятої війни.

А дочка теж усе сумує, Та гіркі сльози пролива, Вона і днями і ночами Нещасну долю проклина.

\section{Вірш:}

Ой, мамо моя мила,

Нащо на білий світ пустила

Не голод муки одала,

А я й не думала й не снилось

У цій Німеччині бувать,

А на чужій землі далекій

Прийдеться з голоду вмирать.

Бодай ліса ці погріли

Бодай цей лагер заваливсь,

А ми б пішли б на Україну

До рідненьких сміючись.

А мати лампу погасила б,

Бо знає, що дочка вже спить

Про її муки і страдання

Вона не може позабить.

63 ДАМО. Ф. Р-2083. Оп. 1. Спр. 42. Арк. 1-1зв. 


\section{Пісня:}

Дам приказ я всем на запад,

Где концлагеря стоят,

Люди бедные страдают

Мы идем их вызволять.

Вот дойдем мы до Берлина

И конец буде войны,

Только родные сестрицы

Вы остантеся живы.

Пускай помнят ваши сестры,

Что продалися они,

Из-за красную повязку

И за мыску баланды.

Мы прийдем и вас научим

Как надо родину любить,

И своих же родных сестер

В ложке супу не топить.

Вы топили не щадили

Век думали с немцом жить,

Но за это вас наградим

Повязки красные носить.

Ваши родные сестрицы

За роботою сидят,

Тихо глазки отпускают

На восток они глядят.

Громко в небе самолеты

Их пропеллеры гудят,

Это русские герои

Нас идут освобождать.

А теперь мы уезжаем

Из Германии домой,

Кто в Германии продался

не берем мы их з собой.

Нам не нужно на Украине

Тех продажников опять,

Лучше будут у Берлине

Для их концлагеря стоять ${ }^{64}$.

Принагідно зазначимо, як бачимо, такі джерела містять одночасно і перлини народного фольклору примусових працівників, що представлені як оригінальними творами (авторськими), так і тими, що побутували серед остарбайтерів у той період. У текстах відображено скрутне становище примусових працівників у трудових таборах, тугу за батьками, сум за Україною, надію на швидке звільнення та повернен-

64 ДАМО. Ф. Р-2083. Оп. 1. Спр. 42. Арк. 2-3. 
ня до України, а також колабораціонізм, перемогу над Німеччиною, покарання за зраду й ін. Спогади Лук'янової Антоніни, яка була депортована у серпні 1943 р. із с. Інгулка Баштанського району та потрапила на роботу до Берліна, містять ще один цікавий емоційний вірш, який називається «Возвращение на Родину»:

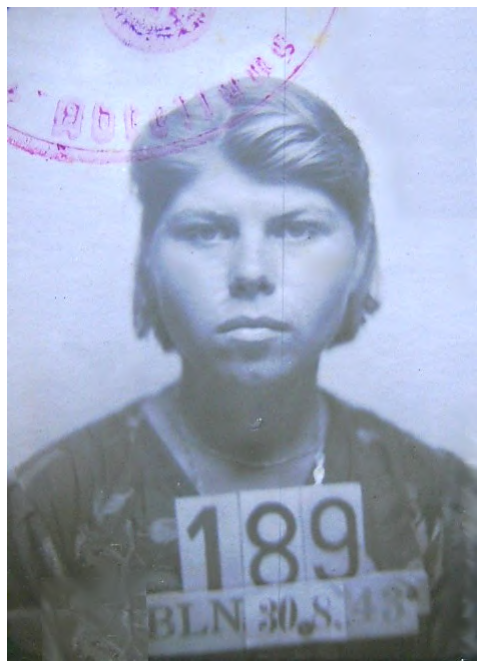

Фото 3. Лук'янова Антоніна. Берлін, 1943 р.

(ДАМО. Ф. Р-5859. Оп. 1. Спр. 12945)
Ночь надвигается вагон шатается, Ко мне спускается тривожный сон, Страна Советская все удаляется, Едет в Германию наш эшелон

Прощайте улицы, родные города Прощайте родные: отец и мать Еду в Германию на муки голода Я еду мучиться и погибать

Но, знайте сволочи, поработители Еще придет на Вас жестокий час, Когда в Берлин войдут герои-мстители И отомстят за всех за нас.

Ночь надвигается вагон шатается, Ко мне спускается спокойный сон, Страна Советская все приближается Едет на Родину наш эшелон!

Да! Здравствуй Родина освобожденная

Привет тебе, любимый край,

Я вновь вернулась к тебе жыланная

Да! Здравствуй Родина и процветай!

Врага разбили герои соколы

Его не будет уж никогда,

Красная Армия непобедимая

Покрыла славою свои дела!65

Покликаючись на документи, маємо можливість досліджувати не лише нелюдське повсякденне життя українських примусових працівників на підприємствах військового-промислового комплексу Третього рейху. Архівні матеріали інколи містить важливі деталі, що розкривають також і трагічні сторінки з історії примусової праці іноземних військовополонених та єврейського населення. Антон Григорович Мацюта у лютому 1944 р. із с. Отбідо-Василівки Снігурівського району був депортований на роботу до східнонімецького міста Фрайберг (Саксонія). 310 березня 1944 р. працював на відновленні чотирьохповерхової будівлі з двома заводськими трубами: розвалювали печі, тягали цеглу на майданчики й ін. Дана будівля призначалась для розміщення у ній виробничих потужностей заводу «Арадо-Верке» (Arado-Werke), що виробляв авіадеталі для німецьких літаків.

Остарбайтерів поселили на 4-му поверсі заводу. На вікнах були встановлені решітки. На третьому поверсі жили військовополонені-італійці. Антон Мацюта на власні

65 ДАМО. Ф. Р-2083. Оп. 1. Спр. 539. Арк. 5. 
очі бачив, як кожного ранку виносили трупи італійців, померлих від голоду.

У кінці березня 1944 р. на цей завод приїхав ешелон з примусовими працівниками-євреями із Польщі та Чехії. Остарбайтерам не дозволяли спілкуватись ні з єврейськими жінками, ні з військовополоненими-італійцями.

У квітні 1944 р. прибуло два ешелони зі станками, які встановили у приміщенні, що було попередньо підготовлено вказаними категоріями примусових працівників. У травні прибували ешелони з алюмінієвими листами. Розпочалась жахлива робота в умовах голоду по 12-14 годин. Клепали деталі для літаків. Режим утримання всіх робітників був нелюдським. 3 табору робітників нікуди не випускали, розмовляти 3 представниками інших національностей заборонялось. У серпні 1944 р. проведено загальний обшук: забрали всі документи та фотографії. Від голоду й виснаження захворіло 300 остарбайтерів з групи, в якій працював Антон Мацюта. Їх вивезли із території заводу і більше вони до табору не повернулись 66 .

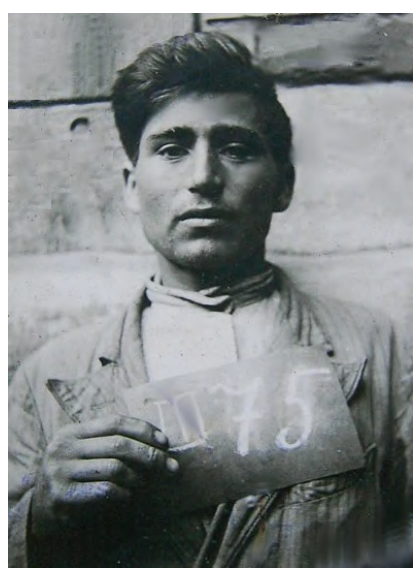

Фото 4. Василь Шевченко. Брауншвейг, $1942 \mathrm{p}$. (ДАМО. Ф.Р-2083. Оп. 1. Спр. 523)

Дані документи дозволяють віднайти важливу інформацію про осіб, вбитих під час перебування на примусовій праці на території Третього рейху, та повернути їх із забуття. Василь Шевченко із земляками з села Гречанівка Снігурівського району у 1942 р. потрапив на роботу на шахту «В.К.В» (B. K. B Gemeinschaftslager Alversdorf / Kr. Helmsstedt), розташовану у районі м.Брауншвейга. Між собою «остарбайтери» перекладали ії як «Брауншвейзька Каторга Більшовиків»67. Тяжкі умови праці забрали життя багатьох його знайомих. Під час одного 3 інцидентів 6 липня 1942 р. вбито його товариша і земляка А. Саприкіна. Через нестерпні умови життя він намагався утекти 3 табору. Але спроба виявилась невдалою, оскільки хтось із «своїх продажних» повідомив про це охоронців, які його поранили у щоку. Затримавши А. Саприкіна, його розстріляли та поховали без труни тієї ж ночі, лише замотавши голе тіло у «паперовий» матрац. Одяг нещасного роздали іншим примусовим працівникам 68 .

Досить часто у документах йдеться про кількість жертв чи травмованих під час нальотів союзницької авіації на різноманітні підприємства, поблизу яких розташовувались трудові табори з примусовими працівниками. Воробйова Анна (Нюра) Григорівна із села Романо-Булгаково Снігурівського району з 1942 р. працювала на одній із фабрик Берліна. Під час березневих бомбардувань союзної авіації (12 березня, ймовірно 1945 р.) її табір було майже повністю знищено. Неймовірна кількість жертв сталась і через те, що працівники не перебували у бомбосховищах. Під час авіаударів їх просто зачиняли у бараках. Таким чином, значна кількість людей загинула від бомб чи просто згоріла у дерев'яних приміщеннях. Їй самій пощастило, що барак завалився від бомбардувань, і вона змогла вилізти з нього. Під час такого нальоту загинуло багато людей: 31500 чоловік залишилось лише 50069.

Навіть після звільнення союзними військами траплялись випадки, під час яких

66 ДАМО. Ф. Р.2083. Оп. 1. Спр. 540. Арк. 45зв.

67 ДАМО. Ф. Р-2083. Оп. 1. Спр. 523. Арк. 2.

68 ДАМО. Ф. Р-2083. Оп. 1. Спр. 523. Арк. 2зв.

69 ДАМО. Ф. Р-2083. Оп. 1. Спр. 380. Арк. 2. 
масово гинули примусові працівники. Йосип Мацько у березні 1944 р. був депортований із села Піски Баштанського району. Працював у приватному господарстві одного із сіл, що розташовувалось на відстані 5 км від німецького м. Триберг (БаденВюртемберг - авт.. ${ }^{70} .24$ квітня 1945 р. об 11-й годині ранку був звільнений французькими військами. Третього травня дізнався, що всіх «росіян» збирали у м. Триберг, звідки наступного дня людей мали перевезти до м. Оффенбурга. Проте у визначений день транспорт з людьми, не доїхавши 5 км до м. Оффенбурга, був повернутий назад до Триберга. Згодом люди дізнались, що ті казарми, в яких їх мали розмістити, були підірвані 4 травня о 3-й годині ранку. Під час інциденту там загинуло тільки «росіян» близько 400 чоловік ${ }^{71}$.

Під час потужних авіанальотів українські примусові працівники часто зазнавали й серйозних травм. Іван Антонович Кондратенко працював у Ганновері на машинобудівному заводі «Hanomag». 9 лютого 1945 р. під час сильного бомбардування міста його поранило у ноги й обидві руки. Через поранення та втрату лівої руки у госпіталі пролежав чотири місяці72.

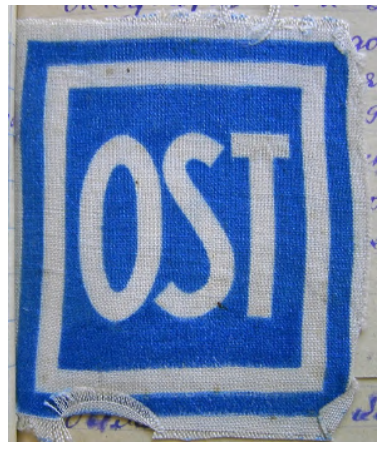

Фото 5. Знак розрізнення «OST», що належав О. Голобородько. (ДАМО. Ф. Р-2083. Оп. 1. Спр. 540)

Окремі епізоди спогадів містять інформацію, що після звільнення примусових працівників деякі з них мстили або ставали свідками такої помсти своїм поневолювачам. Зизда Антоніна розповідала, що у квітні 1945 р. в Ганновері після приходу союзників вихідці із СРСР отримали право на реванш. Люди кинулись на «німецьких звірів»: підпалювали, обстригали, били. Помста продовжувалась два дні, але згодом це припинилось ${ }^{73}$. Левченко Діна згадувала, що німецького бауера (фермера) 3 с. Гамерслебер, у якого вона працювала, забрали до себе американські вояки. Вони одягали його у брудний одяг примусових працівників, змушували працювати, а потім повезли у невідому напрямку ${ }^{74}$.

Особливістю аналізованого корпусу архівних документів $\epsilon$ те, спогади примусових працівників з Миколаївщини містять чимало не введених до наукового обігу фотографій, листів, нетривіальних поштових листівок, трофейних німецьких документів (паспорти, робочі картки, різні посвідки, ощадні книжки тощо), які вони мали здавати до органів НКВС разом з написаними спогадами. Автору вдалося віднайти навіть оригінальні знаки розрізнення, що відображають певні зміни у ставленні до примусових працівників зі Сходу в останній рік війни. Ці знаки належали Олександрі Гаврилівні Голобородько, яка носила їх під час перебування на примусових роботах у Польщі. На-

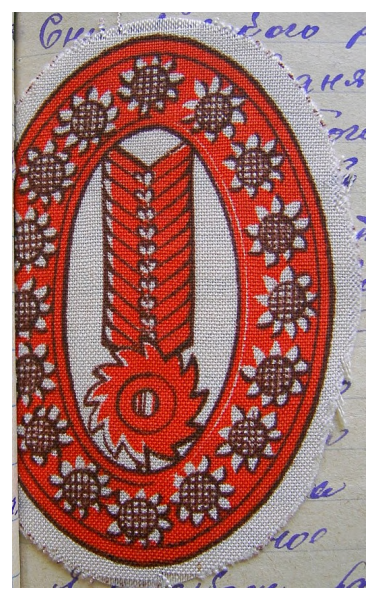

Фото 6. Знак розрізнення «OST», що носила О. Голобородько у 1944-1945 pp. (ДАМО. Ф. Р-2083. Оп. 1. Спр. 540)

\footnotetext{
70 ДАМО. Ф. Р-2083. Оп. 1. Спр. 531. Арк. 8зв.

71 ДАМО. Ф. Р-2083. Оп. 1. Спр. 531. Арк. 9.

72 ДАМО. Ф. Р-2083. Оп. 1. Спр. 326. Арк. 2.

73 ДАМО. Ф. Р-2083. Оп. 1. Спр. 313. Арк. 1зв.

74 ДАМО. Ф. Р-2083. Оп. 1. Спр. 533. Арк. 46-47.
} 
прикінці опису свого «закордонного» досвіду так і написала: «Фотографій я не маю. Листів теж не маю, бо всі листи, що надсилала, не доходили до додому. Здаю тільки знак «OST», який ми носили для розпізнавання, що ми зі Сходу. А в останній час нам видали ознаки для росіян окремо, а для українців - окремо. Я здаю знак, який мали носити українці»75. Варто зазначити, «OST» із зображенням червоно-білих соняшників і пшеничного колосу у середині схожий на той, що мали носити білоруси, а не українці. Як відомо, наприкінці 1944 р. знак «OST» було модифіковано та впроваджено знаки з національною символікою окремо для українців, росіян і білорусів ${ }^{76}$.

Значним доповненням до наративу є унікальні приватні фото, що відображають різноманітні аспекти життя наших земляків: зовнішній вигляд, фрагменти території табору чи зображення житлового бараку, робоче місце й ін. Наприклад, у Ніни Бондар (с. Снігурівка) збереглось колективне фото, що подароване Марією Столяр на згадку про спільні роки примусової праці у Берліні та проживання в одному таборі упродовж 1942-1944 pp.77 Згідно документів Ніни Бондар, назва табору та його адреса така: «Lager Gebauer-Wiesen, Berlin NW87, Beusselsrt. 44»78. На світлині (фото 7) зображено фрагменти заводської території, автопричіп з маркуванням однієї з німецьких фірм з берлінською адресою, група працівників у робочому одязі.

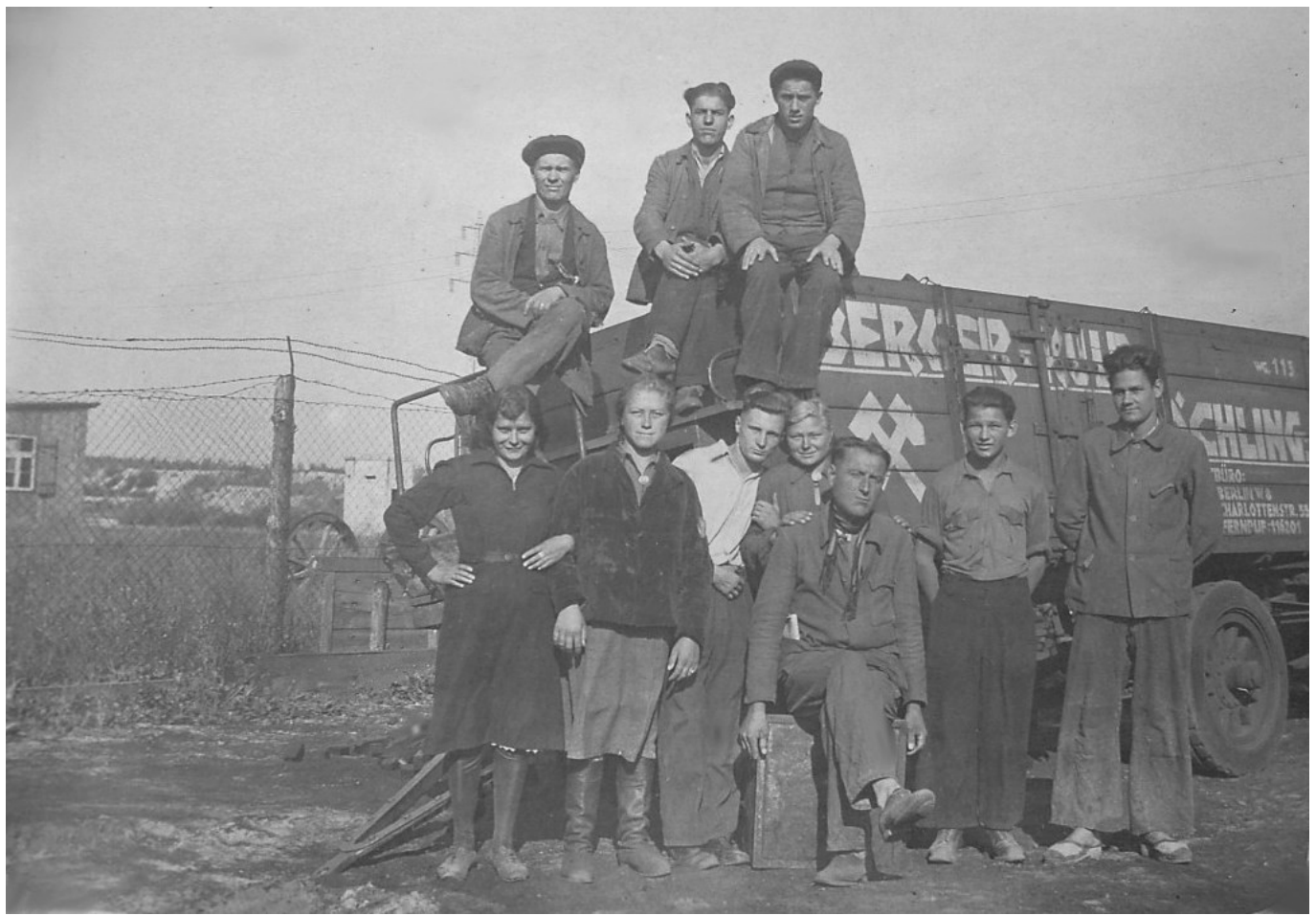

Фото 7. Світлина, подарована Марією Столяр Ніні Бондар. Берлін, 18.09.1944 p.

(ДАМО. Ф. Р-2083. Оп. 1. Спр. 368)

75 ДАМО. Ф. Р-2083. Оп. 1. Спр. 540. Арк. 22зв.

76 Енциклопедія історії України: У 10 т. / Редкол.: В. Смолій (голова) та ін. Т. 7: Мл-О. Київ: Наукова думка, 2010. С. 673.

77 ДАМО. Ф. Р-2083. Оп. 1. Спр. 368. Арк. 4.

78 ДАМО. Ф. Р-2083. Оп. 1. Спр. 368. Арк. 5. 


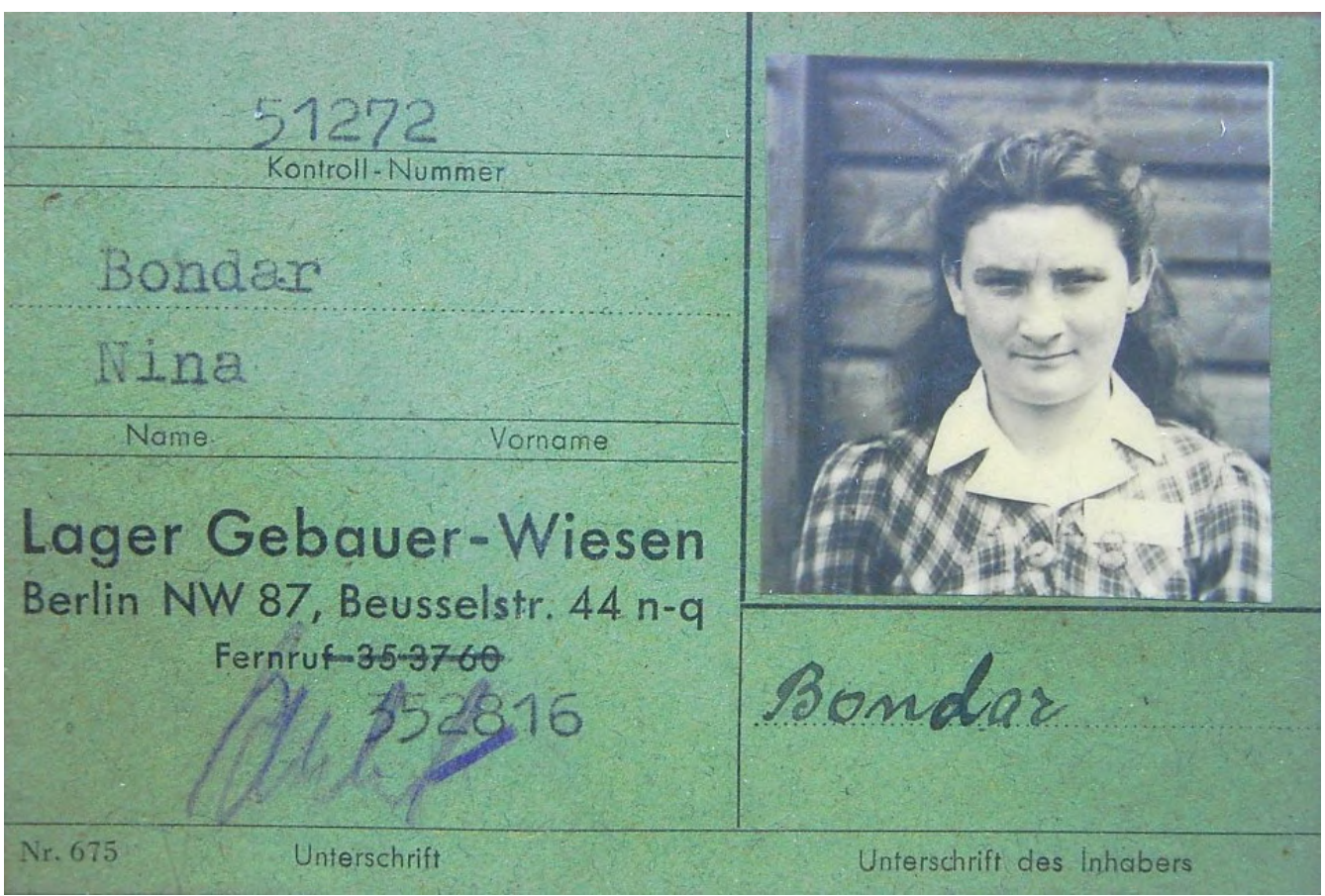

Фото 8. Робоча перепустка Ніни Бондар. Берлін, 1942 р. (ДАМО. Ф. Р-2083. Оп. 1. Спр. 368)

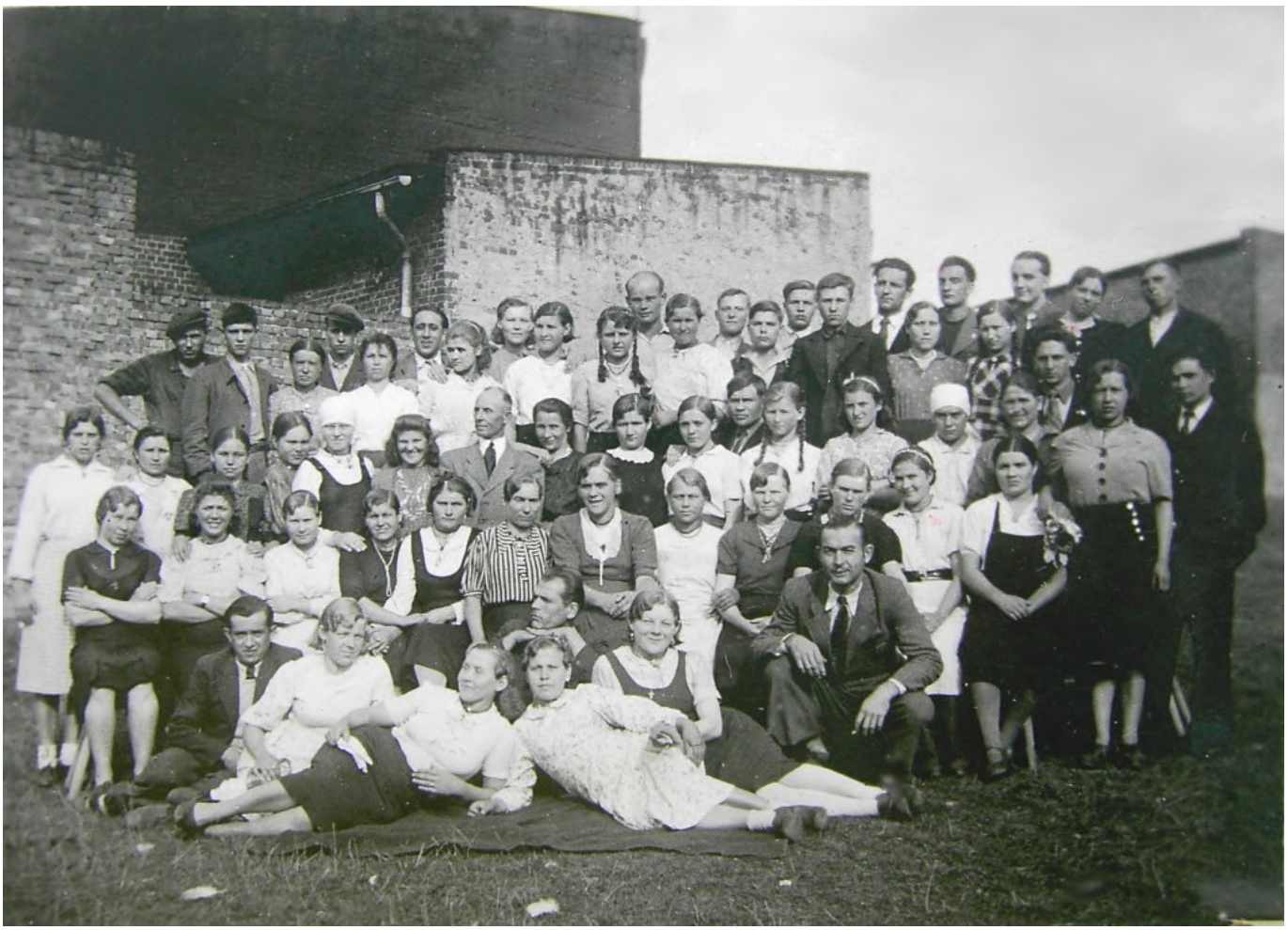

Фото 9. Група примусових працівників. Тарновец, Польща. (ДАМО. Ф. Р-2083. Оп. 1. Спр. 382) 
Надзвичайно цікавими $\epsilon$ світлини Ніни Гаврик, яка була вивезена із с. Новотроїцьке Снігурівського району у жовтні 1942 р. та працювала електрозварювальником на фабриці у польському місті Тарновец (Tarnowiec). На жаль, світлина не підписана (фото 9), тому неможливо точно вказати де і коли зроблена, хто на ній присутній. У спогадах зазначено, що у таборі було 50 дівчат, 14 хлопців і 10 французів $^{79}$. На нижчевказаній світлині видно, що фото зроблено у дворі якоїсь фабрики. На фото присутні близько 60-ти осіб, більшість яких є примусові робітники, які жили у таборі та працювали на фабриці. Ймовірно, на фото присутні і майстри фабрики, французькі примусові працівники 80.

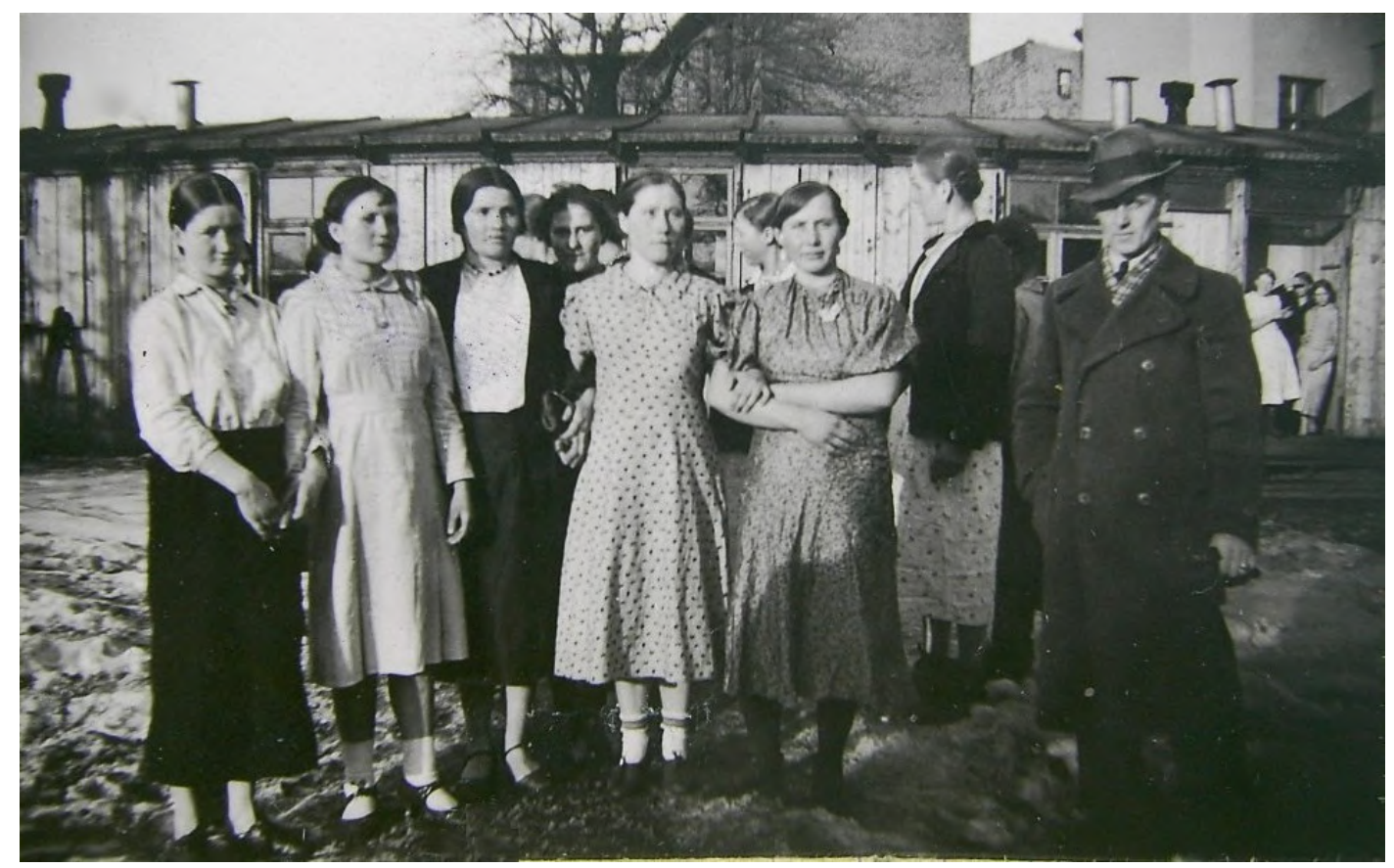

Фото 10. Група примусових працівниць біля бараку. Тарновец, Польща.

(ДАМО. Ф. Р-2083. Оп. 1. Спр. 382)

Інша світлина (фото 10) зроблена посеред табору, який знаходився біля фабрики або, можливо, навіть на їі території, оскільки позаду упритул до бараку видно високі стіни фабричної будівлі81. Дана світлина дає чимало інформації, що дозволяє уявити побутове становище примусових працівників. Дуже чітко видно житловий дерев’яний барак, вікна без решіток, димохідні труби від печей, які остарбайтери мали самі опалювати. На передньому плані присутні шість жінок у святковому чистому демісезонному вбранні та взутті, хоча поруч стоїть чоловік (вочевидь майстер чи представник адміністрації) у теплому зимовому пальті з шарфом і рукавицями, а на землі видніється нерозталий сніг. Позаду них хаотично стоять ще близько семи чоловік, а неподалеку біля входу до бараку - ще троє. Ймовірно, ми бачимо процес фотографування: люди по черзі групами чи самостійно фотографувались, щоб мати

\footnotetext{
79 ДАМО. Ф. Р-2083. Оп. 1. Спр. 382. Арк. 1-3.

80 ДАМО. Ф. Р-2083. Оп. 1. Спр. 382. Арк. 5.

81 ДАМО. Ф. Р-2083. Оп. 1. Спр. 382. Арк. 6.
} 
можливість надіслати світлини батькам чи знайомим. Можна припустити, що фото зроблено взимку 1942-1943 pр. (тобто до моменту, коли їм дозволили виходити 3 табору без супроводу), оскільки з літа-осені 1943 р. остарбайтери надсилали фото, що зроблені у фотостудіях чи вуличних фотокабінах.
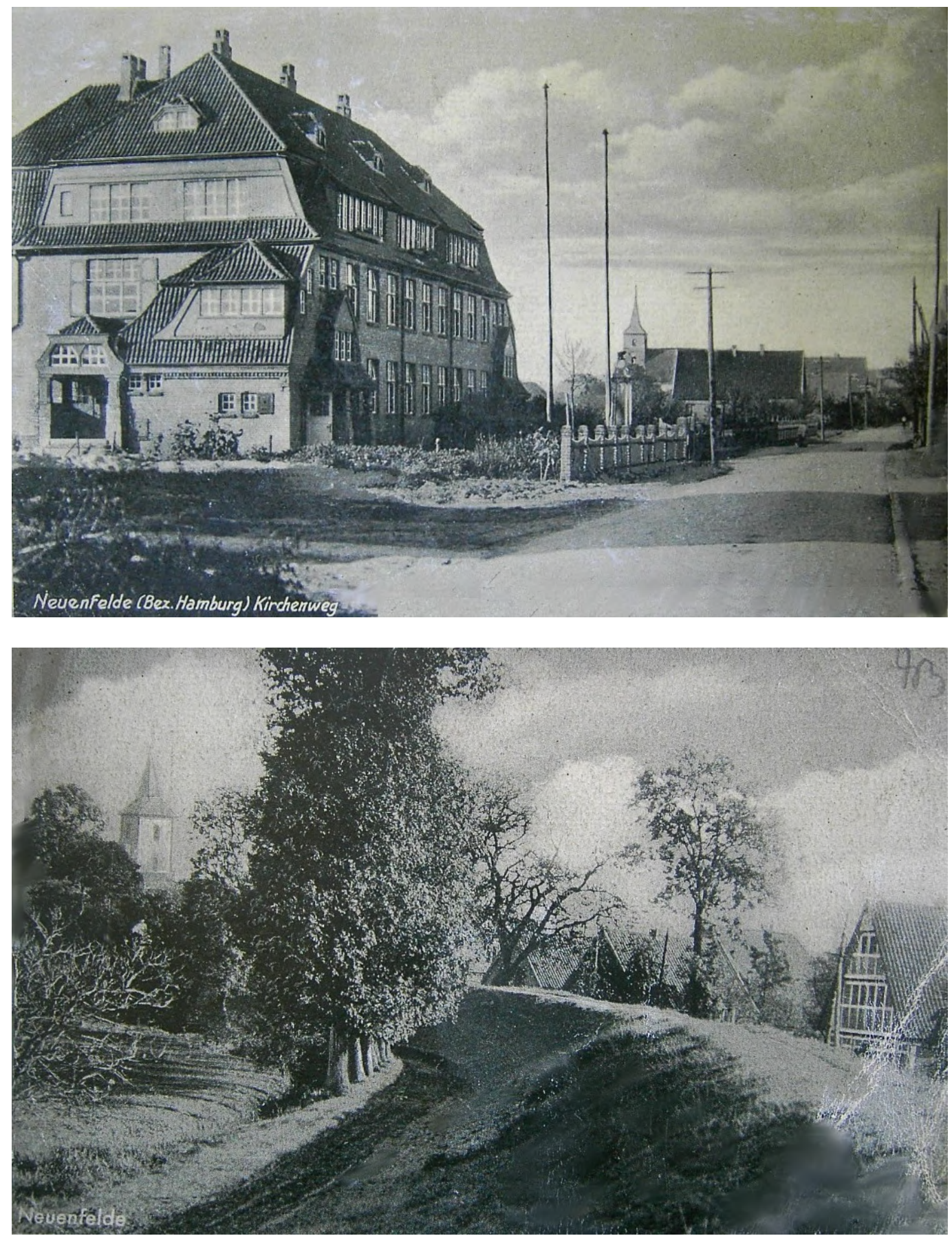

Фото 11-12. Neuenfelde/ bez. Hamburg, Kirchenweg. Зображення на поштових листівках (ДАМО. Ф. Р-2083. Оп. 1. Спр. 540) 
Окремі поштові листівки (без тексту) зберегли гарні краєвиди із стародавньою фахверковою архітектурою сільського кварталу Нойенфельде (Neuenfelde / bez. Hamburg, Kirchenweg), що розташований в одному із семи міських районів Гамбурга - Харбург 82 . На обох листівках видніється церква Св. Панкратія, заснована у XVII ст. Оскільки Гамбург, як і багато міст північної Німеччини, дуже постраждав від бомбардувань британської авіації, то такі автентичні зображення окремих кварталів і будівель зацікавлять і німецьких дослідників.

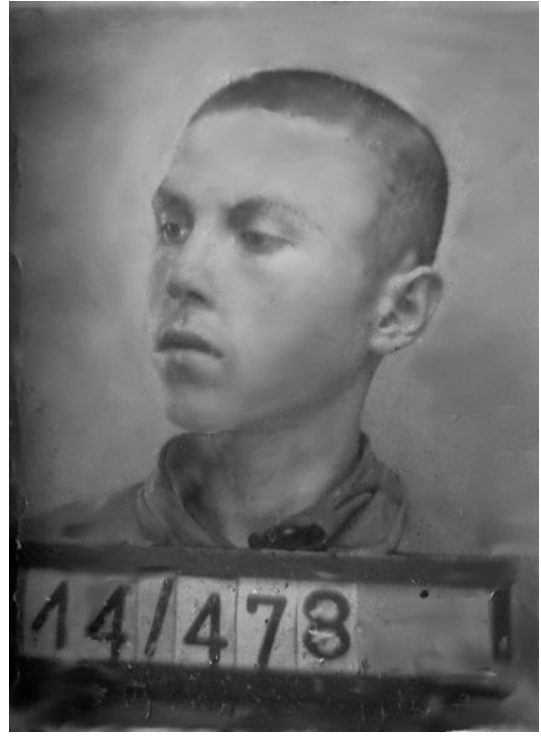

Фото 13. Григорій Козинець. 1944 р. (ДАМО. Ф. Р-2083. Оп. 1. Спр. 529)

Частина документів детально висвітлює масові облави у сільській місцевості, маршрути та способи депортації (залізничним і водним транспортом, піші марші) упродовж лютого-березня 1944 р., масову смертність від хвороб, голоду та загального виснаження, вбивства частини людей конвоїрами, тривалі поневіряння у дорозі та транзитних таборах. Найжахливішими виявились піші багатосоткілометрові марші в умовах весняного бездоріжжя, дощу чи снігу. Чимало людей описує, як їх гнали пішки з Миколаївщини через територію Бессарабії, Румунії і лише в Угорщині садили у вантажні вагони та відправляли до Німеччини чи Австрії. Козинець Григорій згадував, що його вигнали в етап 12 березня 1944 р. 3 Арбузинки людей повели у напрямку Вознесенська, де 16 березня 1944 p. всіх перегнали через р. Південний Буг та погнали далі до Березівки (Одеська область). На цьому відрізку шляху їх супроводжували німці-есесівці, а у Березівці естафету взяли добровольці та поліція.

Серед поліції було 12 чоловік і 2 коменданти із Харківської області.

Із Березівки гнали через Бессарабію. Кожного дня з різних причин конвоїри розстрілювали 7-8 чоловік, з голоду помирало 12-14 осіб. Коли колону пригнали у Румунію, то на ранок померло 86 чол.83 Поліцай Тищук наказав обдерти шістьох туберкульозних напівживих коней і дати м'ясо людям. У результаті половина людей захворіла на кривавий пронос і залишилася на місці. Подальша їх доля невідома.

По території Угорщини решту людей етапували вже мадярські солдати. Коли прибули на одну станцію, то «руська» поліція із комендантом відійшли на формування, до того ж агітували йти з ними як добровольці, щоб даремно не вимирали від голоду. Серед бажаючих виявилися такі «герої» з Кіровоградської області.

Бранців завантажили у потяг і дві доби не давали їсти. Люди страждали від паразитів - воші були й у носі, й у вухах. В ешелоні почався тиф. У вагоні, у якому їхав Григорій Козинець, із 60 чол. залишилось 46, інші померли. Зрештою людей привезли в Австрію та розмістили у таборі за 20 км від Відня. Там провели усім дезінфекцію, видавали 50 г хліба, один раз на добу - шпинат.

Із Відня «остарбайтерів» перевезли до Ерфурта у табір-розподільник. Там люди мучились на карантині та мінімальному пайку ще 20 діб. За цей період захворіло на

\footnotetext{
82 ДАМО. Ф. Р-2083. Оп. 1. Спр. 540. Арк. 81, 83.

83 ДАМО. Ф. Р-2083. Оп. 1. Спр. 529. Арк. 20.
} 
тиф 65\% прибулих людей 84 .

Окремі розповіді містять інформацію, що у 1944 р. такі піші етапи тривали часом упродовж 47-52 діб і закінчувались в Угорщині, звідки вже потягом вивозили далі85. Довготривалі мандрівки, хвороби та карантин з мізерним пайком призводили до того, що чимало людей зрештою потрапляли на роботу тільки після 2-3-х місяців від часу депортації. Для порівняння - упродовж 1942-1943 рр. такі подорожі залізницею (разом і проходженням медичних комісій) тривали у середньому 8-14 днів.

Навіть ті, хто не потрапив до піших етапів, а був вивезений залізницею у кінці лютого - початку березня 1944 р. теж потерпали від складної та тривалої «подорожі». Яків Павлович Нікіфоров 29 лютого 1944 р. із Новомар'ївки Баштанського району був депортований до Німеччини. Його разом із земляками везли товарняками, на яких було написано «rote partisanen». Дорогою випускали раз на дві доби на 5 хв. для «оправки». Їсти давали 200 г хліба та кусень смердючого сира. До м. Ольденбург прибули 27 березня 1944 р. Там він одразу захворів на тиф і 12 діб лежав непритомним. Отямившись, отримував лише 140 г хліба і рідкий бобовий чи бруквяний суп, півстакана віяного молока. У таких умовах хворів до 5 червня 1944 р. Лише 6 червня його виписали з лікарняного бараку та направили на роботу до м. Норден на фабрику з виробництва черепиців.

Одна з тем, яку зі зрозумілих причин поверхово описували колишні примусові працівники, - це труднощі під час повернення українських репатріантів до СРСР, обмеження прав з боку радянського командування чи керівництва. Ці фрагменти спогадів переважно пронизані «ейфорією» від звільнення або ж містять дуже стислий виклад за схемою «звільнення - проходження фільтрації - дата прибуття за місцем проживання», що обмежуються декількома реченнями. Лише окремі з них дають уявлення про те, що «радість від звільнення» була затьмарена мобілізацію значної частини колишніх примусових працівників до трудових батальйонів (залучення вже радянською владою до примусової праці колишніх «остарбайтерів»), їх тривала експлуатація у підсобних господарствах військових частин і відповідно повернення додому через 6-12 місяців, інколи значно довший період.

Так, наприклад, Люба Левчук працювала у районі німецького міста Цайц (Саксонія-Анхальт). У 1945 р., коли вона потрапила до радянської зони окупації, то у таборі м. Цвіккау колишніх примусових працівників посортували: старих і вагітних відправляли додому, а працездатних продовжували використовувати на роботах на території Німеччини ще упродовж шести місяців, де розбирали трофейні заводи, фабрики й ін. ${ }^{87}$

Низка фрагментів нижчевказаних спогадів колишніх примусових працівників з Арбузинського району дозволяє більш детально простежити, до яких видів робіт радянське командування залучало українське населення, що прибувало із зон окупації союзних військ. Семен Іванович Криш-

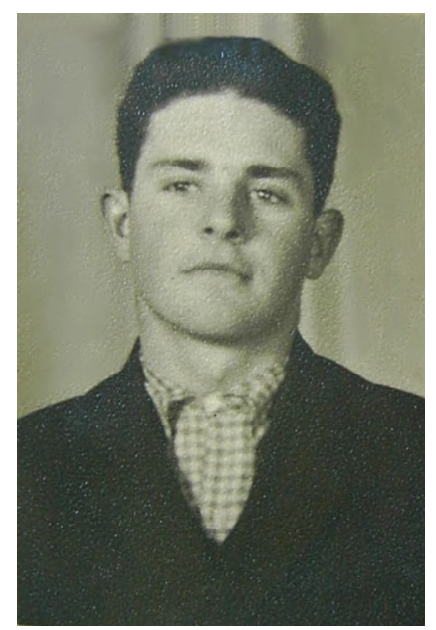

Фото 14. І. Кришко. $02.10 .1945 \mathrm{p}$.

Хемніц, Німеччина. (ДАМО. Ф. Р-2083. Оп. 1. Спр. 529)

84 ДАМО. Ф. Р-2083. Оп. 1. Спр. 529. Арк. 20зв.

85 ДАМО. Ф. Р-2083. Оп. 1. Спр. 541. Арк. 12, 22.

86 ДАМО. Ф. Р-2083. Оп. 1. Спр. 531. Арк. 22.

87 ДАМО. Ф. Р-2083. Оп. 1. Спр. 533. Арк. 49.

Eminak, 2019, 3 (27) 


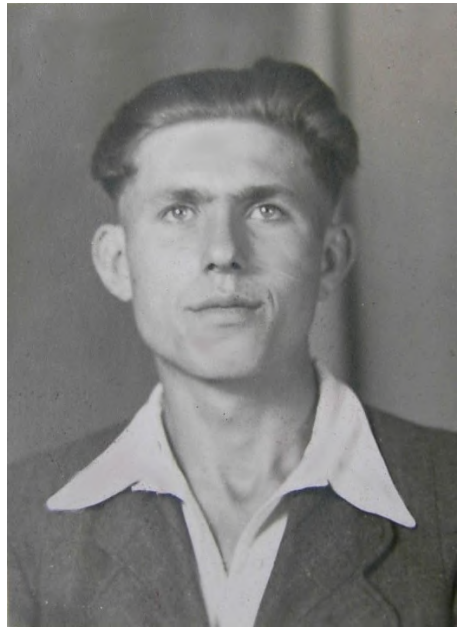

Фото 15. М. Соломічев.

15.09.1944, с. Гаутероде, Німеччина.

(ДАМО.Ф. Р-2083. Оп. 1. Спр. 529)

ко з серпня 1944 р. працював у приватному господарстві у с. Гаутероде (Hauteroda, Тюрінгія). Після «звільнення» у травні 1945 р. перебував у м. Різа. Звідси вивезений радянським командуванням у збірнопересильний пункт м. Рюгланд, де був зарахований до Наркомбуду й у складі робочих батальйонів демонтував, пакував і відправляв трофейну електростанцію до СРСР. У місті Рюгланді загалом пробув близько 2,5 місяців. У цей період також ремонтував бензиновий завод «Бробак», працював на посаді санітара 9-ї сотні до 16 серпня 1945 р. Потім його у складі інших робітників перевезли до міста Хемніц. Там також займались демонтажем обладнання заводів, працював комірником-інструменталістом до 30 жовтня 1945 р. Згодом потрапив до м. Вольфен, де працював на посаді перекладача у 450-му цеху у лейтенанта Кобелєва. Робота полягала у демонтажі електрообладнання, конструкції окремих цехів тощо. 16 грудня 1945 р. всіх знову перевезли із міста Вольфен до м. Рюгланд. Тут вже працювали на відновленому бензиновому заводі «Бробак», який виробляв готову продукцію для потреб Радянської армії. Загалом був залучений до трудової повинності до лютого 1946р.88 Разом з ним працювали Микола Соломічев89 та Іван Чулков ${ }^{90}$.

Клічановська Євдокія (Дуся) Семенівна. Вивезена на примусову працю у серпні 1943 р. із села Максимівка Снігурівського району. Працювала на цукровій фабриці та військовому заводі у м. Бреслау. Її звільнили радянські війська 9 лютого 1945 р. Проте повернутись одразу додому не судилось. Ї̈̈ та багатьох інших жінок направили на роботу у підсобне господарство при військовій частині, де тривалий час вони доглядали трофейну худобу91. Начальник Яковенко обіцяв їм, що хто буде старанно працювати, тим першим напишуть характеристику та дозволять погнати худобу в Україну, крім того, кожній видадуть корову. Там трудилися з 1 березня по 27 липня 1945 р. Працювали добросовісно: кожна мала по 10 дійних і 15 недійних корів, доглядали корів, як своїх. Робота була нелегкою: корів доїли, мили, чистили, напували два рази та годували буряками три рази на день. Так минав час, а дівчат ніхто не відпускав. По худобу приїжджали колгоспники з Київської області, гуртували iï та гнали в Україну. А жінки без кінця та краю отримували нову худобу, змушені були знову та знову

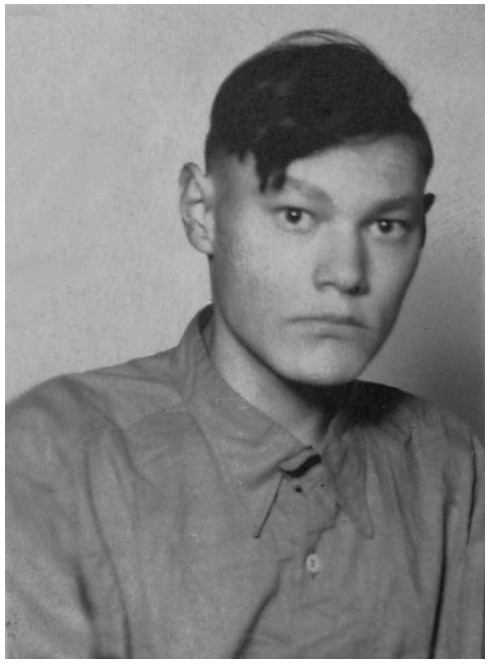

Фото 16. Іван Чулков. (ДАМО. Ф. Р-2083. Оп. 1. Спр. 529)

88 ДАМО. Ф. Р-2083. Оп. 1. Спр. 529. Арк. 26.

89 ДАМО. Ф. Р-2083. Оп. 1. Спр. 529. Арк. 48-49.

90 ДАМО. Ф. Р-2083. Оп. 1. Спр. 529. Арк. 65-66.

91 ДАМО. Ф. Р-2083. Оп. 1. Спр. 540. Арк. 29зв. 
доглядати їі. Лише у кінці червня 1945 р. їх відправили у перевірочно-фільтраційний пункт, а потрапили додому аж 9 липня 1945 р. Після повернення не раз згадувала цього Яковенка, а також те, що ніхто їм так і не видав ні корови, ні навіть маленького теляти ${ }^{92}$.

Під час репатріації непростою виявилась доля людей, які створили родину під час перебування на примусовій праці у Німеччині. Марія Антонівна Пранчук була депортована у грудні 1942 р. із с. Воєводське Первомайського району. У Німеччині працювала у м. Штутгарті. У таборі «Валіндорф № 1123» вийшла заміж за Сергія Тимофійовича Попова та народила від нього дитину. Проте під час повернення до України родина репатріантів була розділена. Ї̈̈ чоловіка мобілізували на роботу та відправили у Приуралля, де він знаходився в Андрєєвському поселенні Оханського району Молотовської області. На час написання спогадів (жовтень 1946 р.) Марія Пранчук згадувала, що від чоловіка вже чотири місяці не отримувала ніякої звістки ${ }^{93}$.

Частина молоді потрапляла на відновлення промисловості Донбасу. Михайло Мазуренко, звільнений американськими військами, до 20 червня 1945 р. перебував у таборі для вихідців з СРСР у м. Франкфурті. Звідти усіх перевезли до м. Хемніц, згодом - у м. Загане. Там жили рівно місяць. Пройшли особливий відділ, а потім всіх, придатних до служби у Радянській армії, відправили у Кенігсбрюк (20 км від м. Дрездена). Там чоловіків записали у запасний полк. Упродовж 1,5 місяців проходили вишкіл, особливий відділ та оформляли документи. 3 Кенігсбрюка молодь перевезли у с. Родатичі поблизу м. Львова, де у всіх забрали посвідчення та сформували 42-й робочий батальйон. 23 вересня 1945 р. цей батальйон прибув у м. Єнакієве Сталінської області. Михайло Мазуренко був зарахований до четвертої роти, що працювала на відновлені шахти імені Карла Маркса. Лише через два місяці за висновками комісії його звільнили з роботи та дозволили повернутись на попереднє місце проживання. До с. Антонівки прибув 5 грудня 1945 р.94

Таким чином, описаний корпус документів $\epsilon$ цінним джерелом з вивчення деяких аспектів довоєнної історії, періоду нацистської окупації, мікроісторії наших земляків в умовах примусової чи рабської праці, повоєнного руху репатріантів. Родзинкою досліджуваного фонду $\epsilon$ наявність декількох унікальних знаків розрізнення («OSTiв»), надзвичайно цікавої фольклорної спадщини, індивідуальних і колективних світлин, приватних листів остарбайтерів, різноманітних німецьких документів, що дозволяють візуально ідентифікувати авторів і додатково ілюструють повсякденне життя, емоції населення Миколаївщини в умовах примусової праці на теренах Третього рейху.

На повноті відображення власного досвіду примусової праці та мотивації виїзду людей до Третього рейху у даній колекції, безперечно, позначились ті обставини, що вони писались в умовах повоєнної недовіри радянського керівництва й органів безпеки до осіб, які пережили окупацію та побували за межами СРСР, а також, власне, страху громадян перед «системою». Через це у спогадах відсутній низка сюжетів повсякденного життя колишніх остарбайтерів на території Третього рейху: добровільність виїзду на примусову працю (у деяких випадках); дозвілля молоді у післяробочий час або у вихідні дні (відзначення свят у таборах, дозволи на самостійний вихід для прогулянок до міста); їх ставлення до німецької історико-культурної спад-

92 ДАМО. Ф. Р-2083. Оп. 1. Спр. 540. Арк. 30.

93 ДАМО. Ф. Р-2083. Оп. 1. Спр. 535. Арк. 48зв.

94 ДАМО. Ф. Р-2083. Оп. 1. Спр. 535. Арк. 37зв.

Eminak, 2019, 3 (27) 
щини, порядків; інтимні стосунки; в окремих випадках лояльне ставлення корінного населення країн, де працювали українці, чи більш-менш нормальні умови роботи; труднощі повоєнної репатріації й адаптації у повоєнному радянському суспільстві й ін.

Залучення до наукового обігу наявних архівних документів сприятиме поглибленому дослідженню процесу депортації мешканців Південної України на примусову працю i, особливо, їх повсякденного життя упродовж 1942-1945 рр. на території Третього рейху та країн-сателітів.

Перспективами подальших досліджень є: стихійний чи організований опір населення Південної України під час перебування у трудових таборах; причини переведення примусових працівників до концтаборів та їх стратегія виживання в умовах рабської праці; особливості депортації січня-березня 1944 р. (піші етапи, масова смертність тощо); дослідження впливу радянської ідеології, цензури на повоєнні спогади та порівняльний аналіз з усними свідченнями, зібраними в часи незалежності України.

\section{REFERENCES}

Avramenko, Yu. \& Kapliuk, V. (2010). Vony buly ostarbaiteramy... / Sie waren Ostarbeiter... rozpovidi kolyshnikh brantsiv natsystskoi Nimechchyny z Pereiaslavshchyny pro yikhne perebuvannia u Tretomu reikhu [They were ostarbeiters... / Sie waren Ostarbeiter... stories of former Nazi Germany prisoners from Pereyaslav Region about their stay in the Third Reich]. Pereiaslav-Khmelnytskyi: SKD [in Ukrainian].

Cherniavskyi, V.V. (2016). Pod znakom «OST»: ostarbaitery s yuga Ukrainy v Tretem reikhe i Rumynii (1941-1956) [Under the sign «OST»: Ostarbeiters from the south of Ukraine in the Third Reich and Romania (1941-1956)]. Nikolaev: Ilion [in Russian]

Cherniavskyi, V.V. \& Zhivotovskaia, V.V. (Comps.). (2017). Za graniu chelovechnosti. Sudby ostarbaiterov $v$ dnevnikakh $i$ vospominaniiakh [Beyond Humanity. The Fates of Ostarbeiters in Diaries and Memories]. Nikolaev: Ilion [in Russian].

Demydov, M. (Ed). (2008). Pamiat zarady maibutnoho: pro diialnist Ukrainskoi spilky viazniv - zhertv natsyzmu ta spohady [Remembrance for the Future: Activities of the Ukrainian Union of Prisoners and Victims of Nazism and memories]. Vol. 3. Kyiv, Feniks [in Ukrainian].

Grinchenko, G. (Ed.). (2009). "Proshu vas mene ne zabuvaty»: usni istorii ukrainskykh ostarbaiteriv [«Please don't forget me»: oral stories of Ukrainian Ostarbeiters]. Kharkiv: Pravo [in Ukrainian].

Grinchenko, G.G. (Comps.). (2004). Nevyhadane. Usni istorii ostrabaiteriv [Not fictionals. Oral ostarbeiters stories]. Kharkiv: Vydavnychyi Dim «Raider» [in Ukrainian].

Hatsa, 0. (Comps). (2001). Pamiat zarady maibutnoho: z istorii desiatyrichnoi diialnosti Ukrainskoi spilky viazniv-zhertv natsyzmu ta spohady [Remembrance for the Future: from the history of ten years of activity of the Ukrainian Union of Prisoners and Victims of Nazism and memories]. Vol. 1. Kyiv: KMTs «Poeziia» [in Ukrainian].

Hatsa, 0. (Comps). (2005). Pamiat zarady maibutnoho: pro diialnist Ukrainskoi spilky viazniv-zhertv natsyzmu ta spohady [Remembrance for the Future: Activities of the Ukrainian Union of Prisoners and Victims of Nazism and memories]. Vol. 2. Kyiv [in Ukrainian].

Marmilova, O.S. (2017). Dzherela do vyvchennia istorii ostarbaiteriv z Donechchyny [Sources to scrutinize the History of Ostarbeiters from the Donetsk Region]. (Candidate's thesis). Vinnytsia [in Ukrainian].

Medchuk, M. (2005). Z lystiv ta spohadiv prymusovykh robitnykiv Tretoho reikhu (za fondamy Derzharkhivu Mykolaivskoi oblasti) [From letters and memoirs of forced workers of the Third Reich (by funds of the State Archives of the Nikolaev area)]. Arkhivy Ukrainy. Naukovo-praktychnyi zhurnal, 1-3 (256), 418-425 [in Ukrainian].

Meliakov, A.V. (2003). Masovi dzherela $z$ istorii deportatsii tsyvilnoho naselennia Kharkivschyny do Nimechchyny $v$ period 1941-1943 rr. [The mass sources for history of deportation the civilian of the Kharkiv region in the period 1941-1943]. (Candidate's thesis). Kharkiv [in Ukrainian].

Nahaiko, T.Yu. (Comps.). (2010). Dzherela pamiati: Istoryko-kraieznavchyi almanakh. Vol. 2: Ostarbaitery: zhyva pravda - zhyvyi bil [Memory Sources: Historical and Local History Almanac. Vol. 2: Ostarbaiters: the living truth is the living pain]. Pereiaslav-Khmelnytskyi [in Ukrainian]. 
Pastushenko, T.V. \& Pershyna, T.S. (2010). Ostarbaitery [Ostarbeiters]. In Entsyklopediia istorii Ukrainy (T. 7, pp. 673-674). Kyiv: Naukova dumka [in Ukrainian].

Smolii, V.A. (Ed.). (2006). «...To bula nevolia». Spohady ta lysty ostarbaiteriv [«...It was a captivity». Memories and letters of ostarbeiters]. Kyiv: Instytut istorii Ukrainy [in Ukrainian].

Turchyn, T.R. (2017). Dzherela do vyvchennia istorii prymusovoi pratsi ta repatriatsii ukraintsiv Stanislavschyny (1941-1953 rr.) [Sources to studying History of the compulsory work and repatriation of Ukrainians from Stanislav region (1941-1943)]. (Candidate's thesis). Ivano-Frankivsk [in Ukrainian].

\section{Anatolii Pogorielov}

(Mykolayiv National University named after V. Sukhomlinsky, Mykolayiv, Ukraine)

ORCID: https://orcid.org/0000-0002-6566-4241

\section{Collection of Post-War Memoirs of Ostarbeiters from Mykolaiv Region: from Informative Potential to Microhistory}

Despite a large number of publications by both Ukrainian and foreign scholars, the process of attracting narrative information and regional source complexes is still ongoing in historical science to research comprehensively the microhistories of millions of Ukrainians deported for forced labor to the Third Reich and its satellites in the years of World War II. One of the main sources that researchers now actively use is the memoirs of former forced laborers (Ostarbeiters); their collecting began in the mid-1990s and intensified since the 2000s. However, some unique collections of memories created in certain regions as far back as 19451946 and being preserved since now have been missed by most researchers. Some of their extracts were used by local historians and archivists in publications, exhibited in online exhibitions, but there is no comprehensive study of all the materials as a whole.

The author's goal is to analyze the information potential of post-war memoirs of Mykolaiv region former forced laborers and to uncover the main microhistorical facts of Ostarbeiters' everyday life and the peculiarities of this group of historical sources.

As a conclusion, it is necessary to say that this group of documents is a valuable source for the study of some aspects of pre-war history, the period of Nazi occupation, the microhistories of our countrymen in the conditions of forced or slave labor, and the post-war movement of repatriates. The special thrill of the studied fund is the presence of several unique identification marks («OSTs»), extremely interesting folklore heritage, individual and collective photos, private letters of Ostarbeiters, various German documents that allow to identify visually the authors and additionally illustrate the conditions of everyday life, and emotions of Mykolaiv region population in the conditions of forced labor on the territories of the Third Reich.

The completeness of describing their own forced labor experience and motivation to leave for the Third Reich in this collection of sources undoubtedly depended on the fact that they were written in the conditions of the Soviet leadership and security agencies post-war distrust for the people who went through the occupation and had been outside the USSR, and citizens' fear of the «system» as well. Because of this, some facts of everyday life in the memoirs of the former Ostarbeiters in the Third Reich were missed.

Prospects for further research: spontaneous or organized resistance of the South of Ukraine population in labor camps; reasons for forced laborers transferring to concentration camps and their survival strategy in slave labor conditions; peculiarities of January-March 1944 deportation (going on foot, mass mortality, etc.); studying of the Soviet ideology, and censorship influence on post-war memoirs, and their comparative analysis with oral evidence collected during the time of Ukraine's independence.

Keywords: Ostarbeiters, post-war memoirs, trophy documents, photos, Mykolaiv region, the Third Reich 